\title{
SUMMARY OF EXPERIMENTS ON THE SILVER VOL- TAMETER AT THE BUREAU OF STANDARDS AND PROPOSED SPECIFICATIONS
}

\author{
By E. B. Rosa and G. W. Vinal
}

\section{CONTENTS}

Page

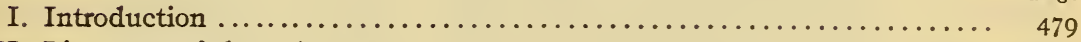

II. Literature of the voltameter............................ 482

III. Summary of the voltameter work at the Bureau of Standards......... 485

IV. Specifications for the silver voltameter................... 497

I. Previous specifications. ........................ 497

2. Specifications proposed by the Bureau of Standards......... 499

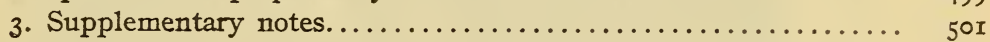

Appendixes.................................................... 507

Appendix A.-Bibliography of the silver voltameter, with a few papers on closely allied subjects................................ 507

Appendix B.-Errata to the preceding papers.................... ${ }_{5}^{1} 3$

\section{INTRODUCTION}

The investigation of the silver voltameter at this Bureau was first begun by the late Dr. K. E. Guthe in I904. His results were published in two papers ${ }^{1}$ about a year later. The work was taken up again at the Bureau in 1907 , when Dr. N. E. Dorsey, in cooperation with the present authors, began what was intended to be a short series of determinations to accompany the absolute measurements of current with the Rayleigh balance, which was then under construction. The results obtained at this time did not altogether confirm the experiments of the National Physical Laboratory which were then newly published, and new difficulties arose which were not understood. These experiments were not published.

In the following year the work was resumed and preparations for a very thorough study of the silver voltameter were made. The voltameter received added importance when the ampere 
was adopted by the London Electrical Congress as the second fundamental electrical unit, so that the investigations which the present authors began in the summer of Igos have passed beyond the original plans in scope and duration. This has also been due in large measure to the numerous and intricate sources of error which were discovered in the course of the work, all of which required painstaking investigation.

Several photographs of the laboratories devoted to the voltameter work are of interest as a matter of record. Fig. I shows part of the voltameter laboratory during the time that the work of Parts I to IV and the comparison of the silver and iodine voltameters was in progress. The apparatus for controlling the current and measuring the time are clearly shown, as well as the voltameters themselves. Another view of this same room which, however, does not show much of the apparatus was published in the paper on the comparison of the silver and iodine voltameters (vol. IO, p. 427 ). Figs. 2 and 3 show the new voltameter laboratory (except the chemical laboratory). This was equipped with the same apparatus brought from the old laboratory when the electrical division of the Bureau moved into its new building. Fig. 3 shows the entrance to the constant temperature balance room. The balances were read by the telescopes and scales which are seen at the windows on either side of the door. In this new laboratory the experiments on inclusions in the silver deposits were made, and also some experiments for the paper on the volume effect. In addition to this suite of rooms, a small chemical laboratory completely equipped was reserved for the preparation and testing of the silver nitrate.

Other experimenters have cooperated with the present authors during the last seven and one-half years, and their names appear on the various publications in which they were particularly concerned. First of these was Dr. A. S. McDaniel, who joined us in July, I909, to study the effects of filter paper on silver-nitrate solutions and to devise means for the purification and testing of silvernitrate solutions. He also investigated a number of other chemical questions which arose during the time he was a member of the Bureau staff. Dr. McDaniel resigned from the Bureau in March, I9r3. A few months later Dr. S. J. Bates, who was research associate in chemistry at the University of Illinois, came to the Bureau to conduct experiments on the iodine voltameter operated in series with the silver voltameter. The result of this work was to establish with greater precision than before the value 
Bulletin Bureau of Standards, Vol. 13

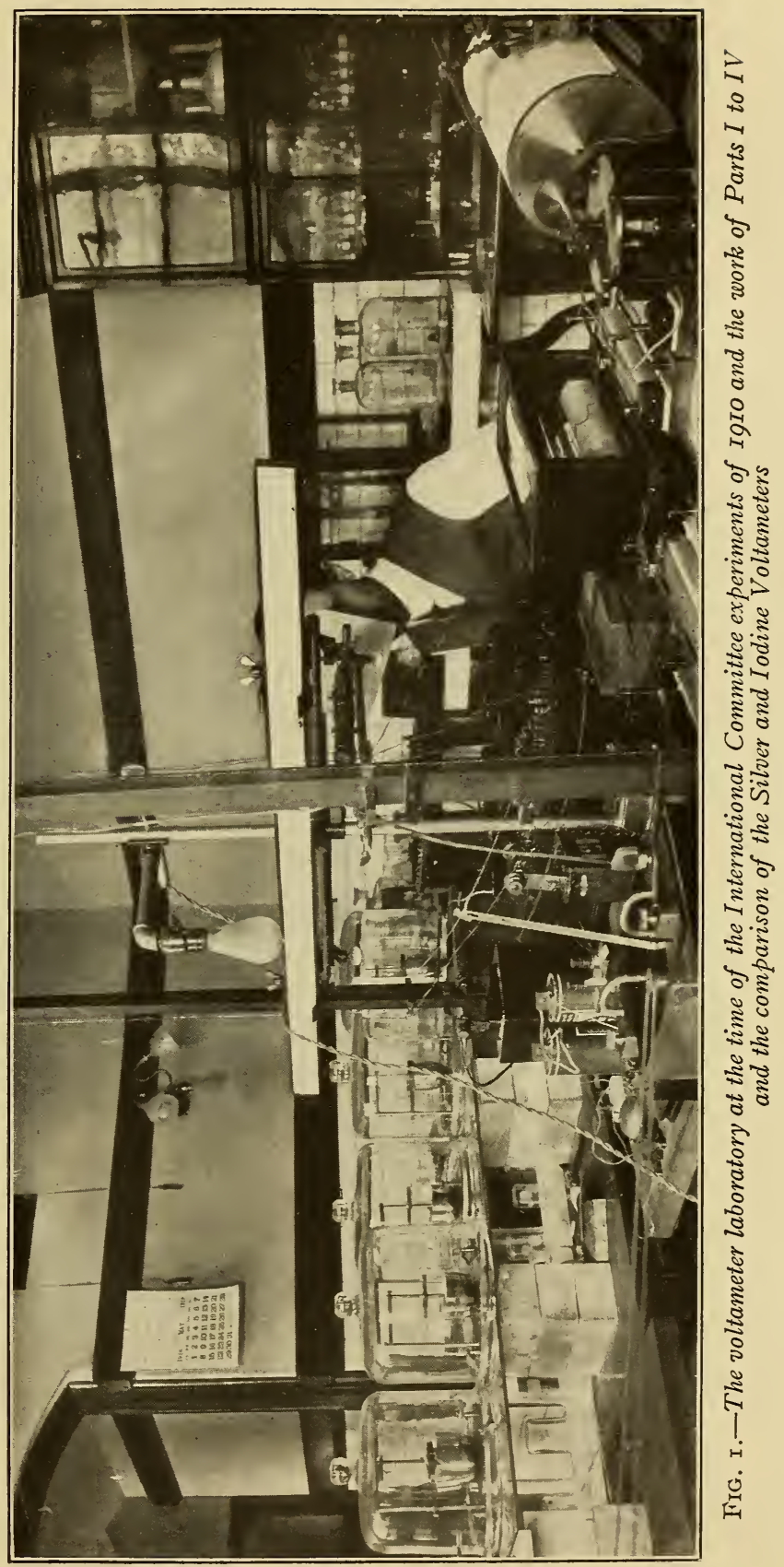


Bulletin Bureau of Stancards, Vol. 13

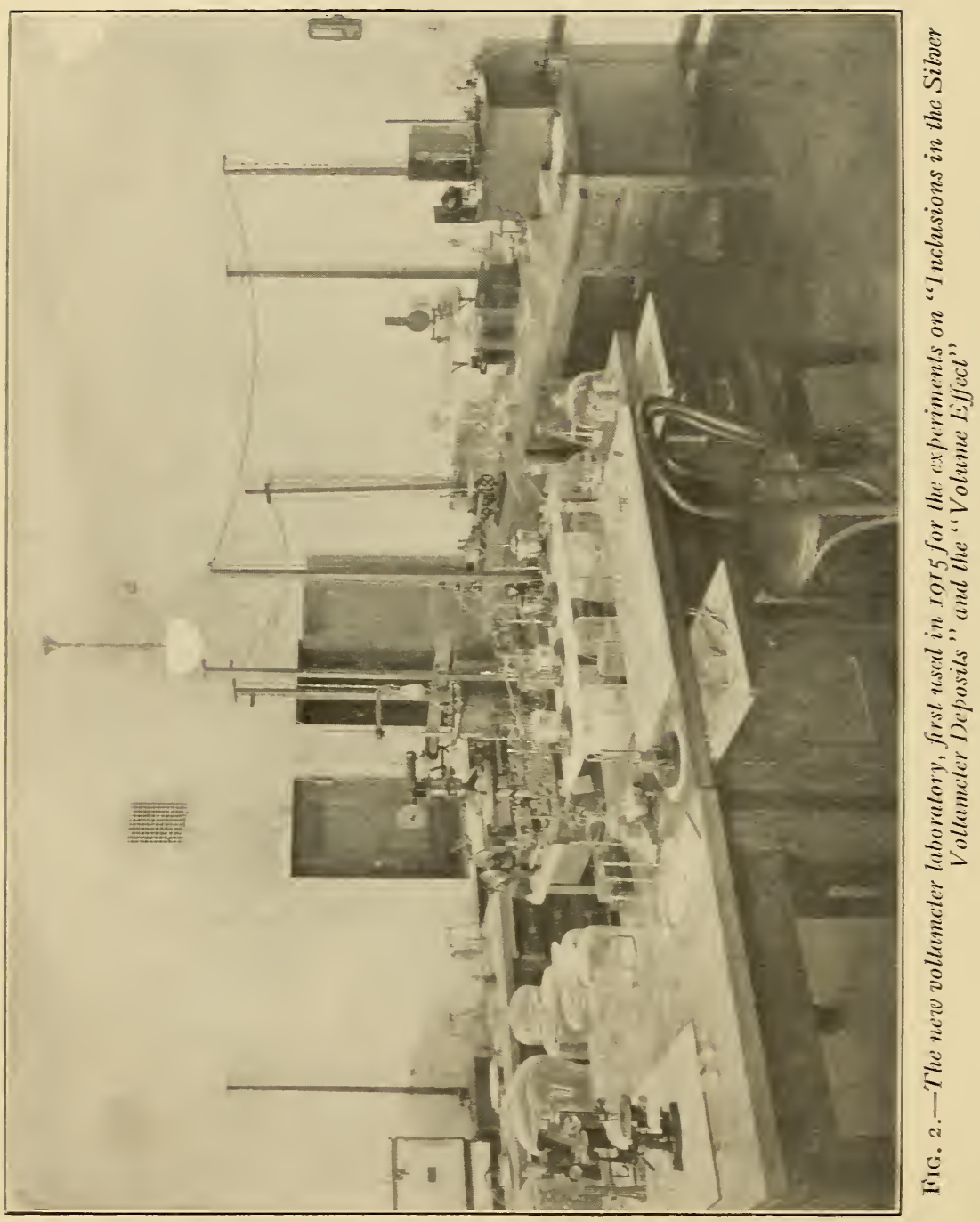


96500 coulombs as the value of the Faraday. For five months in the early part of I9I4 we cooperated with Prof. G. A. Hulett, professor of physical chemistry in Princeton University, in making joint comparisons of methods and materials for the silver voltameter, during which a previously neglected source of error in washing the deposits was discovered. Lastly, William M. Bovard, assistant in chemistry in Princeton, has collaborated at the Bureau in a determination of the foreign material included in the silver deposits.

It seems desirable at the present time to summarize the investigations that have been in progress at the Bureau since 1908 in order that the results of these experiments may be put forward with our proposed specifications for the silver voltameter as a measurer of electric current. Accordingly, in the present paper we present a résumé of the preceding papers which are listed below, and a specification for work of the highest precision with the silver voltameter which embodies the results of these investigations.

The present investigations of the voltameters have been published in the following papers:

The Silver Voltameter:

Part I, First Series of Quantitative Experiments, by E. B. Rosa and G. W. Vinal. This Bulletin, 9, p. I 5 I (Reprint No. I94).

Extended abstracts in J. Wash. Acad. Sci., 2, p. 45I, I9I2; Elec. World, 60, p. I26I, I9I2; Elektrotech. Zs., 34, p. 232, I9I3.

Part II, Chemistry of the Filter-Paper Voltameter and the Explanation of Striations, by E. B. Rosa, G. W. Vinal, and A. S. McDaniel. This Bulletin, 9, p. 209 (Reprint No. 195).

Extended abstracts in J. Wash. Acad. Sci., 2, p. 509, I9r2; Elec. World, 60, p. I262, I912; Elektrotech. Zs., 34, p. 233, I913.

Part III, Second Series of Quantitative Experiments and the Preparation and Testing of Silver Nitrate, by E. B. Rosa, G. W. Vinal, and A. S. McDaniel. This Bulletin, 9, p. 493 (Reprint No. 20I).

Extended abstracts in J. Wash. Acad. Sci., 3, p. 40, I9r3; Elec. World, 61, p. 84, r9r3; Elektrotech. Zs., 34, p. rr68, r9r3.

Part IV, Third Series of Quantitative Experiments and Special Investigations, by

E. B. Rosa, G. W. Vinal, and A. S. McDaniel. This Bulletin, 10, p. 475 (Reprint No. 220).

Extended abstracts in J. Wash. Acad. Sci., 4, p. 52, I9I4; Elec. World, 63, p. 373, I9I4; Elektrotech. Zs., 35, p. 789, I9I4.

Comparison of the Silver and Iodine Voltameters and the Determination of the Value of the Faraday, by G. W. Vinal and S. J. Bates. This Bulletin, 10, p. 425 (Reprint No. 2I8); J. Am. Chem. Soc., 36, p. 9I6, I9I4.

Extended abstract in J. Wash. Acad. Sci., 4, p. 69, I9r4.

Studies on the Silver Voltameter, by G. A. Hulett and G. W. Vinal. This Bulletin,

11, p. 553 (Reprint No. 240); J. Phys. Chem., 19, p. I73, I9r5.

Extended abstract in J. Wash. Acad. Sci., 4, p. 593, I9I4.

$67154^{\circ}-\operatorname{vol} 13-16-9$ 
Inclusions in the Silver Voltameter Deposits, by G. W. Vinal and W. M. Bovard. This Bulletin, 13, p. I47 (Reprint No. 27I); J. Am. Chem. Soc., 38, p. 496, IgI6.

The Volume Effect in the Silver Voltameter, by E. B. Rosa and G. W. Vinal. This Bulletin, 13, p. 447 (Reprint No. 283).

\section{LITERATURE OF THE VOLTAMETER}

In our first paper we gave a brief review of about 60 of the principal papers dealing with the silver voltameter, and in our later publications we have discussed some papers that have appeared since. There are, howerer, a considerable number of papers that have not been mentioned. A fer of these are referred to below, but in an appendix a list is given of references dealing with the voltameter, which includes the papers previously discussed and a considerable number of other references. This list is possibly not complete, but it is believed that it includes practically all papers which report the results of investigations on the silver voltameter as an instrument of precision. It also includes many papers in which the voltameter was used simply to measure the quantity of electricity passing through the circuit and some references dealing with the various forms in which silver is deposited by the electric current, etc.

A very old paper which has recently come to our attention is interesting enough to call for brief notice here. It is by William Sturgeon, ${ }^{2}$ who was sometimes inclined to be a severe critic of Faraday and his experiments. In view of the present universal acceptance of Faraday's laws of electrolysis and the use of the voltameter principle for a primary electrical standard it is somewhat amusing to read Sturgeon's views of Faraday's voltameter, as follows:

The instrument certainly measures the gases liberated by the electric current, especially the hydrogen when collected separately, and in that capacity becomes an electrogasometer; but it has no pretensions whatever to the dignified rank of a measure of either the absolute or relative quantities of the electric matter transmitted. The idea of its indicating the extent of action in the voltaic battery would be perfectly absurd.

In I9I I Prof. Egoroff ${ }^{3}$ published a preliminary account of the work which was being done on the electrical units at the Russian laboratory. This included experiments on the silver voltameter of the form designed by F. E. Smith, but no quantitative experiments are recorded since the work was interrupted by the death of M. Lebedev. These experiments have now been continued by

2 Sturgeon's Annals of Electr., 1, p. ${ }_{369} ; I_{3} 6$.

? Report of Bu. of Wts. and Meas., Petrograd, p. I22; IgII. 
Bulletin Bureau of Standards, Vol. 13

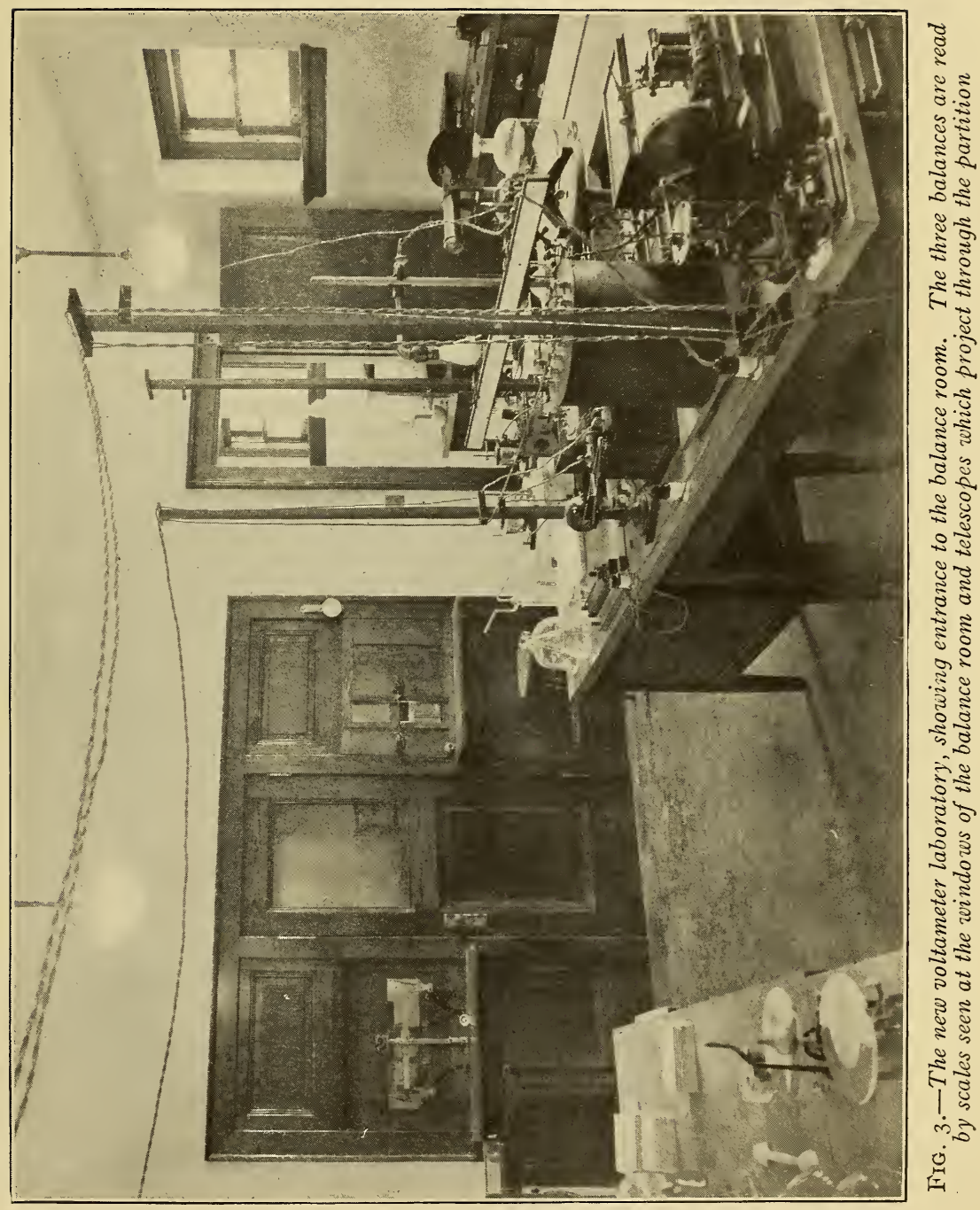


Mile. Ferringer. ${ }^{4}$ She has determined the voltage of some of the Weston cells prepared for the Russian Bureau of Weights and Measures. Four determinations with the voltameter of cell $\mathrm{E}$ average very nearly r.or 830 .

Boltzmann ${ }^{5}$ published in I9I 2 an account of his careful researches on the voltameter. He made tests for inclusions in his deposits by the method of heating the cups and deposits to a high temperature. Without mentioning the formation of platinum black in this process, the precautions which he took in preparing the cups probably eliminated this as a source of error in determining the inclusions. The results which have been recently obtained at this Bureau are in substantial agreement with Boltzmann's determinations of the inclusions. ${ }^{6}$ He found a slightly greater deposit of silver when the deposits were made on a previous deposit than when they were made on the bare platinum. The results led him to conclude that this was due to an initial deposition of hydrogen on the bare platinum. We think this conclusion correct, but probably it occurs only under special conditions. We made special experiments ${ }^{7}$ to determine the possibility of the deposit being diminished by an initial deposition of hydrogen ions on the ordinary platinum cups and found that this was not the case. The recent work done here on the matter of inclusions will, however, afford a ready explanation of the phenomenon observed by Boltzmann. We may reasonably assume that his cups after heating to redness contained a slight alloy of silver and platinum which would leave a thin layer of platinum black when the silver was removed. Boltzmann tells us that he glowed the cups before making the next deposit and this would convert the platinum black to platinum gray. The platinum gray, as we have shown, does cause a diminution of the deposit, probably owing to its catalytic action on the hydrogen ions. The important point here, however, is that Boltzmann's explanation holds, in our opinion, only when the cup contains platinum gray, which is an abnormal condition. He made experiments on the anode liquid and found it without effect on the cathode deposit. He also made experiments on the effect of light on the voltameter, with negative results.

Haga and Boerema ${ }^{8}$ made a careful determination of the voltage of the Weston normal cell, using a tangent galvanometer, and

\footnotetext{
4 Electritchestvo, 35.13, p. 260; I914.

5 Sitzber. Akad. Wiss. Wein, II A, 121, p. I05I.

This Bulletin, 13, p. 16I (Reprint No. 27I).

7 This Bulletin, 10, p. 507 (Reprint No. 220).

${ }^{8}$ Arch. Neer. Sci. 3, p. 324; 1913.
} 
in addition made determinations with the silver voltameter, finding I.OI826 international volts at $20^{\circ} \mathrm{C}$ for the cell and I.II8O2 $\mathrm{mg}$ per coulomb for the absolute electrochemical equivalent of silver. These are in excellent agreement with the values found by ourselves. ${ }^{9}$

Cohen ${ }^{10}$ investigated the validity of Faraday's first law at high pressures. He arranged a voltameter which could be subjected to 500 atmospheres pressure and compared it with a similar voltameter in free air. He found no appreciable difference between them due to the pressure.

A paper by Lowry, ${ }^{11}$ dealing with the solvent properties of silvernitrate solutions, is an important contribution to the voltameter literature because of its bearing on the purification of silver nitrate. The paper gives quantitative data on the amount of chlorides, bromides, iodides, and sulphides held by silver-nitrate solutions at different concentrations and temperatures.

Jaeger and Von Steinwehr ${ }^{12}$ published a short paper in 1914 referring to the names of the different types of voltameter. Prior to April, I9I0, we had referred to an arrangement of the voltameter consisting of a glass dish underneath the anode as the Kohlrausch voltameter. ${ }^{13}$ In deference to what we understood to be Dr. Jaeger's opinion on the question we ceased to call this arrangement the Kohlrausch voltameter, and subsequently referred to it as the Poggendorff voltameter. This, however, was not what was desired, and we are taking this opportunity to correct the matter. The Kohlrausch form of voltameter being especially used in Germany, it is proper to designate it according to the usage of that country. It is now our understanding that the arrangement which we have described as the Poggendorff voltameter ${ }^{14}$ when used without silk or other organic wrapping around the anode should be called the Kohlrausch voltameter. When an organic covering of the anode is used, the instrument is not properly to be called a Kohlrausch voltameter. We show in Fig. 4 a photograph of a Kohlrausch voltameter as we have recently used it at this Bureau. The matter of names for the various types of instruments is more a matter of convenience than of vital importance. We have frequently referred to the porous-cup voltameter as the Richards voltameter, although Prof. Richards was not the first to use a porous cup around the anode. ${ }^{15}$ In a more recent paper of Jaeger

This Bulletin, 10, pp. 477,486 (Reprint No. 220). ${ }^{10}$ Zs. f. Phys. Chem., 84, p. 83 ; 1913. ${ }^{11}$ Proc. R.S., 91; p. 53; I9I4. ${ }^{12}$ Elektrotech. Zs., 35, p. 8Ig. ${ }^{13}$ Supp. to Rept. to Internat. Com., p. I8, footnote 8. 14 This Bulletin, 9, p. I73 (Reprint No. I94). 15 The use of a porous cup is mentioned in the $188_{3}$ edition of Wiedemann's Elektricitat, p. 49r. Probably Poggendorff may be said to have first used the porous cup. Pogg. Ann., 75, p. $337 ; 1848$. 
Bulletin Bureau of Standards, Vol. 13

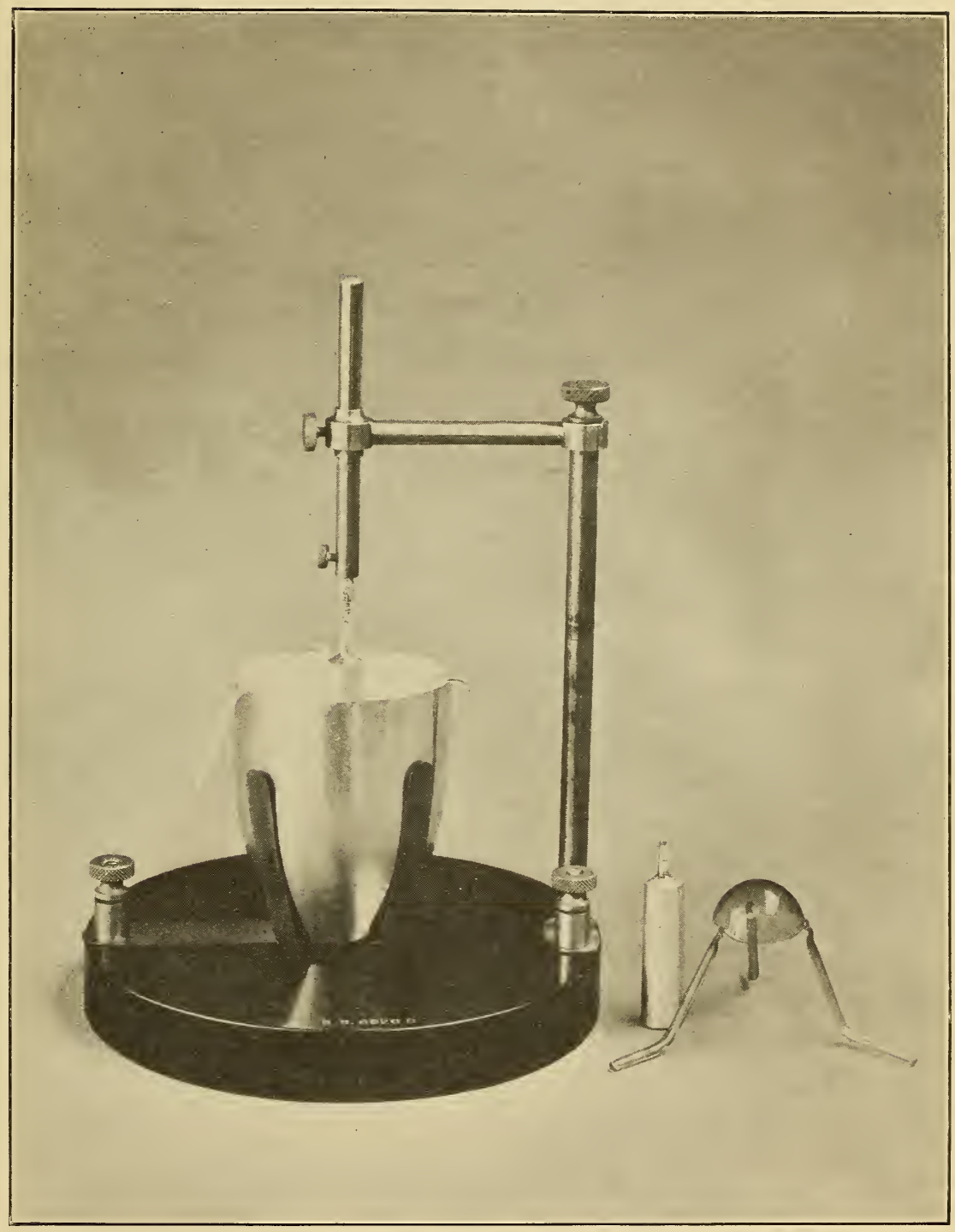

FIG. 4.-The Kohlrausch voltameter 
and Von Steinwehr ${ }^{16}$ they express the opinion that Richards and Anderegg have not proved their conclusions as to the inclusions in the silver-voltameter deposits, and they also state that we have not shown the volume effect in any other form of voltameter than the porous-cup form. In answer to this latter statement we have recently published ${ }^{17}$ a rather full account of our experiments on the volume effect, including some experiments made recently.

In a note in the October (1916) number of the Journal of the American Chemical Society, Richards and Anderegg correct some statements made in their earlier paper ${ }^{17 a}$ and admit the correctness of the silver voltameter work of the Bureau of Standards, and also admit the presence of errors in their own work which vitiated their conclusions as to the magnitude of the inclusions in the silver deposit.

Since this paper has gone to press we have received a copy of Obata's paper on the voltameter. ${ }^{17 b}$ He has made careful measurements of the voltage of the Weston cell, finding $1.01826_{9}$ volts at $20^{\circ} \mathrm{C}$. He also investigated the effect of acid in the voltameter and obtained a relation almost identical with that which we gave. ${ }^{17 c}$

\section{SUMMARY OF THE VOLTAMETER WORK AT THE BUREAU OF STANDARDS 18}

When the international technical committee met in Washington in the spring of rgro to carry out voltameter measurements and to determine the voltage of the Weston normal cell, we presented to the delegates a report ${ }^{19}$ of our work previous to that time. This report was in the form of short paragraphs summarizing our conclusions. We have made use of much of the material in that report in what follows, but it has been rearranged and revised. In addition to this we have added the conclusions drawn from our subsequent work. To each paragraph is appended a series of references to the principal places in our papers, as published in the Bulletin, where the experimental results or a more complete discussion may be found. These references are designated by the volume and page of the Bulletin. They furnish a ready guide to the preceding papers, but can not be regarded as a complete index.

I. ${ }^{20}$ The use of filter paper in the silver voltameter gives an abnormal deposit which is usually striated and from $\mathrm{I}$ to 5 parts in

${ }^{16}$ Zs. f. Instrk., 35, p. 225; I915. ${ }^{17}$ This Bulletin, 13, p. 447. ${ }^{17 a}$ J. Am. Chem. Soc., 37, p. 7. ${ }^{173}$ Proc. Tokyo Math. Phys. Soc., 8, p. 437, rgr6. 17 c This Bulletin, 10, p. 482.18 With the cooperation of A. S. McDaniel, S. J. Bates, G. A. Hulett, and W. M. Bovard. ${ }^{19}$ Supp. to Rept. to Internat. Com., p. 7. 20 This Bulletin, 9, pp. 196, 199, 215, 222, 511 . 
Io 000 too heavy. Using a minimum quantity of filter paper the effect is proportionally decreased, but an excess in weight is always found which in precise work is far too much to neglect. Different grades of filter paper produce approximately the same effect if used in equal quantities. A preliminary washing of the filter paper with dilute alkali and water reduces the excess but does not eliminate it.

2. ${ }^{21}$ The striations and excess in weight are also produced if instead of placing the filter paper in the voltameter while the silver is being deposited it is allowed to stand in the electrolyte for a time before the latter is electrolyzed, the clear solution being poured or filtered off and electrolyzed in a voltameter without filter paper. If the electrolyte is merely filtered through filter paper before electrolysis, an appreciable increase in the weight of silver mill be found. Again, if the electrolyte is made up from pure silver nitrate and distilled water in which latter filter paper has stood for some time, the deposit will be striated and too heavy. The water poured off from the filter paper contains something (oxycellulose and cellulosehydrates) extracted from the filter paper, and we have called this soluble extract for convenience "filter-paper extract."

3. ${ }^{22}$ This effect of filter paper in producing striated deposits offered a valuable means of tracing out the nature of its action upon the electrolyte. By this means, and also other methods, the influence of filter paper upon the electrolyte was established.

4. ${ }^{23}$ The constituents of the filter paper which are active in the voltameter are soluble in water, since aqueous extracts of filter paper produce even more pronounced effects than the filter paper itself. Yet these active substances can not be foreign impurities associated with the cellulose of the filter paper, since repeated extraction does not diminish the activity of the filter paper in the voltameter.

5. ${ }^{24}$ Concentrated filter-paper extracts reduce neutral or faintly acid silver-nitrate solution to a wine-red colloidal solution of metallic silver under ordinary conditions. This colloidal solution is permanent in the presence of silver nitrate and other electrolytes, owing to the protective action of the reversible organic colloid which is extracted from the filter paper. This colloidal silver may be coagulated by means of alcohol. The properties and composition of this coagulated silver or hydrogel show it to be

21 This Bulletin, 9, pp. 20I, 205, 213, 23I, 237.

23 This Bulletin, 9, pp. 211, 236, 247, 25I, 259, 270.

${ }^{23}$ This Bulletin, 9, p. 230.

24 This Bulletin, 9, pp. $23 \%, 242$. 
nearly pure metallic silver containing a little organic material. It changes spontaneously into ordinary gray metallic silver under certain conditions, is insoluble in ammonium-hydroxide solution, soluble in 30 per cent nitric acid, soluble in potassium cyanide, and completely amalgamates with mercury at ordinary temperatures.

6. ${ }^{25}$ The reduction of neutral silver-nitrate solution-that is, containing no "uncombined" acid-by filter-paper extract is accompanied by the liberation of nitric acid. The detection of this "free" nitric acid is complicated, however, by the fact that silver nitrate is slightly hydrolyzed in solution and also reacts with litmus and certain other indicators. These diffculties were overcome, however, by precipitating the silver as chloride by means of pure neutral sodium or potassium chloride and filtering by means of asbestos or finely divided platinum; the test is then made upon the filtrate. Tests made in this way show that silver nitrate solution contaminated with filter-paper extract is at first basic (to the same extent as the extract itself when diluted to the same amount), but becomes less basic on standing, and finally acid.

7. ${ }^{26}$ The action of the filter paper (cellulose) is not due to the formation of either silver nitrite or of silver hyponitrite, as suggested by Smith and Lowry, but certain other reduction products of nitric acid, notably hydrazine nitrate, when added to the electrolyte, cause the deposit to become striated. Careful tests showed, however, that none of these reduction products of nitric acid are formed in the voltameter under ordinary conditions.

8. ${ }^{27}$ The action of salts of hydrazine, hydroxylamine, etc., in the voltameter was found to be due simply to their strongly reducing character. Any strong reducing agent capable of precipitating colloidal metallic silver from neutral silver-nitrate solution, when added to the electrolyte, causes the silver deposit to become striated similar to the deposits formed when filter paper is present. Weaker reducing agents, such as cane sugar, starch, hydrocarbons, etc., do not produce these effects. It would thus appear that cellulose (pure filter paper) is a stronger reducing agent than either cane sugar or starch, and that it is this property which causes it to produce such marked effects in the voltameter. 
9. ${ }^{28}$ The strong reducing action of cellulose is due to the formation of a film of oxycellulose on the surface of the fibers when exposed to the air under ordinary conditions. This very small amount of oxycellulose may be almost completely extracted with water (more completely with dilute alkali), but begins to form again immediately on exposure to the same conditions. The concentrated filter-paper extracts, especially the extracts made with dilute alkali, are straw yellow in color and yield appreciable amounts of furfuraldehyde when distilled. Dilute nitric acid increases the amount of furfural obtained by distillation. The strong reducing action of oxycellulose is not due to its decomposition into reducing sugars such as dextrose, but probably to its decomposition into furfuraldehyde. Its colloidal nature also probably influences its reducing properties.

I0. ${ }^{28}$ The oxycellulose extracted is colloidal in character, as revealed by examination with the ultramicroscope. It shows a basic reaction toward methyl orange and iodeosine, and may be accurately titrated against $\mathrm{N} / \mathrm{r} 000$ acid by means of the latter indicator. It is a reversible colloid in the sense defined by Zsigsmondy. Under usual conditions it migrates toward the anode. Only a relatively small amount of this organic colloid reaches the cathode in the silver voltameter, the main portion of the excess weight of deposit in the filter-paper voltameter consisting, we believe, of colloidal metallic silver.

I I. ${ }^{30}$ Raw silk used as a septum instead of filter paper gives at first an effect somewhat similar to that of filter paper, due to its decomposition into an aldehyde; if used repeatedly, acid is produced, and this acts in the opposite direction, decreasing the weight. Sometimes, therefore, the effect of silk may be to increase the weight of the deposit, and sometimes to decrease the weight of the deposit, according to how long it has been used. Raw silk may contain linen or mercerized cotton, in which case its effect is greater. Pure raw silk thoroughly washed produces the effect only slightly.

I 2.31 Polymerized furfuraldehyde when added to the electrolyte in amounts as small as $0.00 \mathrm{I}$ per cent causes the electrodeposited silver to become striated and strikingly similar in appearance under the microscope to the deposits from the filter-paper voltameter.

\footnotetext{
28 This Bulletin, 9, pp. 23I, 232, 237, 252, 254, 256, 260 .

29 This Bulletin, 9, p. 239.

30 This Bulletin, 9, pp. 20I, 202, 232; 10, p. 508.

51 This Bulletin, 9, pp. $236,259$.
} 
I3. ${ }^{32}$ The most important classes of impurities to be guarded against are: (a) Reducing impurities both organic and inorganic; (b) "uncombined" base or acid; (c) abnormal amounts of carbon dioxide; $(d)$ "soluble" or colloidal silica; and $(e)$ positively charged colloids in general.

I4. ${ }^{33}$ The two fundamental conditions for striations are (I) the presence of reducing impurities in the electrolyte and (2) a motion of the electrolyte over the cathode. These must exist simultaneously, as neither can produce striations alone, although the first may modify the crystalline structure of the deposit. The distinctness and color of the striations depend on the relative amount of reducing impurities, except that in the case of a highcurrent density or long-continued current the striations may be bridged over by the deposited metal forming a solid sheet that does not appear striated at the end of the experiment: The deposit from a pure electrolyte, uncontaminated by filter paper or other material, is distinctly crystalline and entirely free from striations. Striations are therefore an evidence of an impure electrolyte, although slight impurity (sufficient to increase the weight appreciably, especially in a large voltameter) may exist without evident striation. The cause of striations and the conditions which determine their distance apart and appearance are fully discussed in the second paper.

I $5 .^{34}$ Colloidal silver in solutions prepared chemically or by Bredig's method travels to the cathode. This is a matter of importance in the explanation of striations.

I6. ${ }^{35}$ The anodes are generally prepared by slowly depositing silver upon them at the same time that the silver is removed from the platinum cups by electrolysis. This may be conveniently done during the night, using a smaller current than in the voltameter deposit. The anodes are subsequently baked, which whitens them and frees them from acid. We have also employed pure commercial silver for anodes and have found it satisfactory, but the anode slime is produced in much greater quantity than upon the electrolytic anodes, hence the latter are to be preferred, especially when no septum is used. We recommend an anode current density not greater than 0.05 ampere per square centimeter.

\footnotetext{
32 This Bulletin, 9 , pp. 222-262, 524; 10, pp. 494-495; 11, p. 556;13, p. 167; 13, p. 447

33 This Bulletin, 9, pp. 200, 211, 270, 279.

34 This Bulletin, 9, p. 219.

35 This Bulletin, 9, pp. 183, 518; 10, pp. 499, 529 .
} 
I $7 .^{36}$ Platinum cups of sereral sizes and gold cups of the smaller size have been used as cathodes. With pure electrolyte the deposits in the various sizes are in agreement. The gold cups agree with the platinum cups and are satisfactory in service, but we do not recommend them in preference to platinum because they are not as durable. The cathodes both with and without deposits have been dried at $150^{\circ}$ in an electric oven. We have seen comparatively little floating silver when washing a deposit in any form of voltameter. This may be left in the bowl by using a siphon to remove the electrolyte and wash waters. After thorough washing with cold distilled water no spots should appear on the deposit after drying in the oven. We recommend a current density not greater than 0.01 ampere per square centimeter.

I $8{ }^{37}$ For the accurate weighing of the cathode bowls it is necessary to have the balances in a room of nearly constant temperature and to protect the bowls from any considerable radiations. To minimize the errors arising from changes of humidity and atmospheric density we prefer to use platinum bowls of equal size as tares. With proper arrangements a $4-g$. deposit is quite sufficient for weighings to be made to a higher accuracy than I part in 100000 of the deposited silver.

I9. ${ }^{38}$ In washing the deposits of silver we have found it necessary to complete the washings on the same day that the experiment is made. We find that the precaution taken by some observers of soaking the deposits overnight leads to a serious error, since silver in contact with platinum is appreciably soluble in water.

$20 .{ }^{33}$ A large variety of voltameters has been used. Among them are the porous-cup form; the nonseptum form, including that designed by Kohlrausch and the modification devised by F. E. Smith, of the National Physical Laboratory; the siphon form in several different arrangements; and the filter-paper form. The last we have found is seriously in error, due to the action of filter paper. (See above.) The siphon form presents great experimental difficulties, due to its high internal resistance and the large volume of electrolyte which may lead to error. There remain, therefore, the porous-cup voltameter, which we have found particularly useful, and the nonseptum forms of Kohlrausch

\footnotetext{
${ }^{26}$ This Bulletin, 9, pp. I70, I $84,187,212,221,522 ; 11$, Pp. 555,$56 ; ; 13$, p. I5I.

$\Re$ This Bulletin, 9, pp. I $7 \mathrm{I}, I 74$, I8I, IS3; 13, p. I52.

3 This Bulletin, 9, D. IS4; 11, D. 55 .

3 This Bulletin, 9, pp. I72, 518; 10, pp. 479, 497, 529;13, p. I5I.
} 
(no silk) and of Mr. Smith. These are the most reliable, in cur opinion, and are in substantial agreement. But it must be noted that a voltameter without any septum may give an abnormally heavy deposit, due to anode slime carried over to the cathode, especially if the anode is very small. Some form of septum is desirable, unless a voltameter arrangement is employed which effectively prevents the formation of anode slime, or in some other way prevents anode slime from reaching the cathode.

2I. ${ }^{40}$ The $\mathrm{AgNO}_{3}$ salt must be purified by recrystallization, with or without subsequent fusion, repeatedly if necessary. The preparation of the salt and the testing for purity we have fully discussed. An electrolyte prepared by dissolving pure salt in pure water does not require filtering. The deposit is, however, unaltered by filtering the electrolyte through asbestos. The presence of a trace of acid ( $I$ or 2 parts in I 000000 ) in the electrolyte affects only slightly the weight of silver deposited. The electrolyte may become slightly acid to this extent during the run when a porous cup is used, but this does no harm.

22. ${ }^{41}$ The water used to prepare the electrolyte has been twice distilled, its specific conductivity lying between $0.8 \times 10^{-6}$ and $2 \times 10^{-6}$. In addition, special care has been taken that the water was neutral toward iodeosine (in ether-water solution) or methyl red as it came from the still.

$23 .{ }^{42}$ The restriction in the official specifications of the London conference that only 30 per. cent of the silver in the electrolyte be deposited is unnecessary. Ten per cent solution of $\mathrm{AgNO}_{3}$ agrees with I5 per cent in the weight of the deposit produced. Using Io per cent solution is more economical of material, and on the whole to be preferred, provided the volume of the cathode electrolyte is not too small. Used cathode solution (made up to Io per cent by adding pure new salt) agrees with Io per cent new solution when the latter is pure. Used solution gives a smaller and more nearly normal deposit than new when the latter is not quite pure; this is due to the impurity being electrolyzed out during the first run.

$24 \cdot{ }^{43}$ If recrystallized silver nitrate containing any amount of acid greater than 0.005 per cent is fused in an electric oven at a temperature between $230^{\circ}$ and $300^{\circ} \mathrm{C}$, and is quickly removed from the oven as soon as completely fused, the salt retains from 0.001 to 0.003 per cent of the nitric acid, and shows no evidence 
of decomposition as indicated by its reaction toward N/I000 permanganate, and by the fact that it gives no volume effect in the voltameter. Salt containing about this amount of nitric acid is, in our opinion, more suitable for voltameter work than when exactly neutral.

25.44 If acid silver-nitrate crystals containing traces of organic impurities are fused as we have described, the product reduced $\mathrm{N} / \mathrm{I} 000$ permanganate. This is a reliable and very sensitive test for small traces of organic material in general in silver nitrate, and is especially valuable for detecting traces of filter-paper contamination. Colloidal silver is oxidized quantitatively by permanganate, one equivalent of the silver requiring one equivalent of the permanganate solution. The anode electrolyte does not reduce thousandth normal permanganate solution if carefully decanted from the anode slime or if filtered through asbestos. If filtered through filter paper, it does reduce quite appreciable quantities of permanganate.

$26 .^{45}$ We have found it possible to make satisfactory tests of the acidity of the electrolyte by precipitating the silver with a neutral chloride and titrating the filtrate with $\mathrm{N} / 1000 \mathrm{H}_{2} \mathrm{SO}_{4}$ or $\mathrm{N} / \mathrm{I} 000 \mathrm{NaOH}$, using either iodeosine in ether-water solution or an alcoholic solution of methyl red. The latter is somewhat simpler to use.

$27 .^{46}$ A careful study of the effect of acid in the electrolyte has been made, showing that it decreases the deposit of silver if the electrolyte is pure. With impure electrolytes the effect can not always be predicted. Acid does not cause a deposition of hydrogen ions before the deposition of silver begins, as some have supposed.

28. ${ }^{47}$ The temperature coefficient of the porous-cup voltameter is zero for a pure electrolyte. Experiments have shown that it is not more than I part in I 000 000 per degree, at least between $20^{\circ}$ and $50^{\circ} \mathrm{C}$, and this is within the errors of the experiment. When the electrolyte contains reducing impurities these will be more active at the higher temperature and therefore a temperature coefficient will appear, as found by Lord Rayleigh and others, but this does not mean that the true electrochemical equivalent is subject to temperature changes.

44 This Bulletin, 9 , pp. 53 I, $534 ; 13$, p. 169 .

45 This Bulletin, 9, p. $526 ; 10$, p. $502 ; 11$, p. 555

46 This Bulletin, 10 , pp. $482,503,505 ; 11$, p. 556

47 This Bulletin, 9, p. 520. 
29. ${ }^{48}$ Large voltameters frequently give larger deposits than small ones, such excess being due to the impurity of the electrolyte. This excess of the deposit in voltameters of larger volume is called the "volume effect." With very pure electrolyte the difference disappears, but we have seldom, if ever, been able to purchase silver nitrate pure enough to show no appreciable volume effect without further purification. The agreement of large and small voltameters in series is an excellent test for the purity of the electrolyte.

$30 .{ }^{49}$ The volume effect is not confined to any one form of voltameter, but has been found in all the forms tested. We have found the large and small sizes of voltameters in excellent agreement when the electrolyte was pure, as shown by our permanganate and acidity tests. With less pure electrolyte, such as we have prepared from "C. P." silver nitrate as purchased, a difference of from 0.2 to $0.8 \mathrm{mg}$ appears, and by soaking a little filter paper in this electrolyte for about ro minutes this difference may be increased to $\mathrm{I} .5$ or $2.0 \mathrm{mg}$. Since we have used the same cathodes, anodes, and porous cups in these tests, the conclusion is obvious that the volume effect arises from the electrolyte and not from the porous cup or other arrangement of the voltameter. With an electrolyte known to be impure we have never found the large and small voltameters in agreement and, on the other hand, with an electrolyte believed to be pure the volume effect has appeared to an appreciable extent in only two or three cases out of a great number of comparisons; these were undoubtedly due to experimental error or to accidental contamination of the electrolyte.

$3 r{ }^{50}$ If the volume of electrolyte in the porous-cup voltameter is specified, it should be the volume of the electrolyte in the cathode space. The volume of the anode liquid above $20 \mathrm{cc}$ for a $4 \mathrm{~g}$ deposit is immaterial.

32. ${ }^{51}$ The siphon form of voltameter with electrolyte as purchased has given, without exception, a larger deposit than the Richards or Kohlrausch forms as used by us. The siphon voltameter with porous cup over the cathode end gives a smaller deposit than without a porous cup, because the latter reduces the volume of the cathode electrolyte. A porous cup over the

\footnotetext{
43 This Bulletin, 9, pp. 168, 514; 10, p. 530; 13, p. 167; 13, p. 447.

49 This Bulletin, 9 , p. $514 ; 10$, p. $530 ; 13$, p. 167; 13, p. 447 .

50 This Bulletin, 9, p. 516 .

51 This Bulletin, 9, pp. 509, 5I6; 10, p. 492.
} 
anode end makes little, if any, difference. However, with electrolyte of highest purity the siphon voltameter probably agrees with other forms, although due to heating it can not be used in absolute determinations and for large sizes it magnifies any slight volume effect.

$33 .{ }^{52}$ No advantage is found in using large porous-cup voltanieters instead of small ones, but on the contrary several disadvantages. They require more electrolyte, can not be meighed as accurately relatively to the amount of silver deposited (unless the deposit is more than usual and more than necessary), are less convenient to handle, and are more expensive. If the salt is not perfectly pure, the excess of the deposit will be greater in the large cups and hence the error multiplied. Four grams can readily be deposited in our smallest cups, representing one-half ampere for two hours. We advise the use of more than one size of platinum cup, however, for testing the purity of the electrolyte, employing the smaller size for standard use. On the contrary, the new form devised by F. E. Smith is more convenient in the large sizes.

$34^{53}$ The porous cups should be fine grained, thin walled, and of low electrical resistance, and after preliminary washing should be kept immersed in good $\mathrm{AgNO}_{3}$ solution before using in the voltameter and between experiments. We find it easy to keep the cups neutral and clean and believe them thoroughly reliable in use. That porous cups are very efficient separators between anode and cathode chambers is shown by the fact that filter paper may be placed inside the porous cups without altering the appearance or weight of the deposit on the cathode. Filtration through a porous cup decolorizes a solution of colloidal metal and also removes the filter-paper extract from an electrolyte or from a water solution. We do not advise cleaning the porous cups with aqua regia and $\mathrm{KCN}$ nor baking them at high temperatures. We use nitric acid for whitening them and distilled water for washing. Heating to a high temperature renders them alkaline. Cups made by the Königlich Porzellan Manufaktur, of Berlin, have been used in most or our experiments, but in the later work we have also used cups made by John Maddock, in Trenton, N. J., with equal success. These latter have the advantage of being provided with solid vitreous tops. Not every kind of a porous 
cup will be satisfactory in the voltameter. We have tried several other kinds and have found them unsuitable, for various reasons.

$35 .^{54}$ Tests on the purity of the deposits have been made in various ways. In the first place, it is to be remarked that the consistency of the results shows either that the inclusions must be very small or very constant in amount. By alloying the deposit of silver with 50 times its weight of mercury we were able to release the inclusions so as to make actually visible organic matter deposited in the silver from solutions which had been strongly contaminated by filter paper, and by means of phenolsulphonic acid small amounts of silver nitrate were detected; but when deposits from pure electrolytes were similarly alloyed, no visible inclusions were found nor was any evidence of silver nitrate as great as $0.00 \mathrm{I}$ per cent found.

An extensive and careful series of tests for inclusions has been made by heating the deposits in the platinum cups to a temperature of $600^{\circ}$ or above, both in an electric furnace and in a flame. Consistent results were obtained, showing as the average of 25 observations a mean loss in weight of the deposit of 0.0040 per cent, which is independent of the size of the voltameter. With deposits from less pure electrolytes we have found inclusions to be greater. We have measured the inclusions between the silver crystals and the cup by an application of the conductivity method and find them to be only about 0.0002 per cent of the silver deposit as a maximum. We have found the method of heating the cups and deposits to expel the inclusions to be subject to a serious source of error, due to the slight alloying of the platinum and silver which results in platinum black when the silver is removed. This must be guarded against the next time the cups are used.

$36 . .^{55}$ Various experiments on the anode solution have been made, since this has been thought to contain an anomalous substance which deposits silver spontaneously and makes the deposit on the cathode too heavy if it is permitted to reach the cathode. We have found that all the effects ascribed to it may be more readily attributed to the presence of impurities in the electrolyte, such as colloidal silver. We have not found anything abnormal about anode solutions which were initially pure.

64 This Bulletin, 9, p. 24I; 10, p. 516;13, p. 147.

65 This Bulletin, 9, pp. 203, 513;10, p. 524;13, pp. 169, 513 (errata, line 5). 
The following determinations have been made in the foregoing papers:

37.56 The voltage of the Weston normal cell at $20^{\circ} \mathrm{C}$ has been found to be I.OI 827 volts. For this determination three long series of observations involving about 300 deposits in the voltameters of various sizes and of both the porous-cup and nonseptum forms have been made. We have used the international ohm as it was defined by the international technical committee. The value for the cell is in international volts and is not corrected for any inclusions in the silver.

38.57 By means of an absolute current balance of the Rayleigh type and our voltameters, using both the porous-cup and nonseptum forms, the absolute electrochemical equivalent of silver is I. I $805 \mathrm{mg}$ per coulomb (not corrected for inclusions in the silver). By applying the corrections for inclusions in the silver (see No. 39 below) we find the absolute electrochemical equivalent of silver to be I.II $800 \mathrm{mg}$ per coulomb.

$39 .{ }^{58}$ Measurements of the inclusions of foreign material in the silver deposits have shown that on the average 0.004 per cent of the weight of the deposit is expelled by heating. This indicates that the deposited silver from pure solution is 99.996 per cent pure silver.

$40 .{ }^{59} \mathrm{By}$ using the silver and iodine voltameters in series and comparing the deposits of silver and iodine, the ratio of silver deposit to the iodine deposit is found to be 0.85017 , which corrected for the inclusions of foreign matter in the silver deposits is $0.850 \mathrm{I} 3_{6}$. This is larger than the ratio of the present international atomic weights of silver and iodine by nearly o.or 8 per cent.

$4{ }^{160}$ In terms of the silver voltameter for calculating the coulombs on the basis of the electrochemical equivalent of silver (I.II800 mg), as defined by the London Electrical Congress of I908, we found the electrochemical equivalent of iodine to be I.3 I $502 \mathrm{mg}$ per coulomb. This is, then, the value in international electrical units. To convert it into the absolute value, assuming the inclusions in the silver deposits to be 0.004 per cent, as stated above, we have to add 0.004 per cent; that is, the value becomes I.3I $507 \mathrm{mg}$ per coulomb.

\footnotetext{
56 This Bulletin, 9, pp. Ig\$, 504; 10, pp. $486,489,490,498$.

$5 i$ This Bulletin, 10, p. 4i\%.

58 This Bulletin, 13, p. I4\%.

59 This Bulletin, 10, p. 442 .

50 This Bulletin, 10. p. 442.
} 
$42 .^{61}$ The Faraday on the basis of the absolute electrochemical equivalent of silver and of iodine and their atomic weights is as follows:

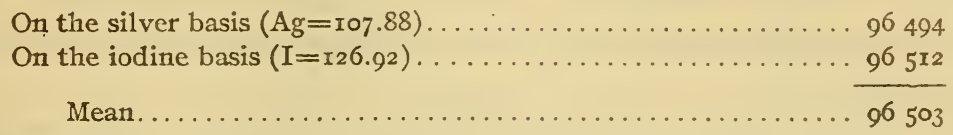

The best round value which can be assigned to this constant appears, therefore, to be 96500 coulombs.

$43{ }^{82}$ Silver deposits in platinum dishes are appreciably soluble in distilled water. The average rate at which the silver is lost from the deposit is $0.006 \mathrm{mg}$ per hour from a $4 \mathrm{~g}$ deposit.

\section{SPECIFICATIONS FOR THE SILVER VOLTAMETER}

\section{PREVIOUS SPECIFICATIONS}

In I89 I the electrical standards committee appointed by the English Board of Trade reported ${ }^{63}$ at the Cardiff meeting of the British association a series of resolutions of which No. ro defined the ampere in terms of the mass of silver deposited according to accompanying detailed specifications. At Edinburgh ${ }^{64}$ the following year representatives of Germany, France, and the United States met with the electrical standards committee to consider the establishment of identical standards in various countries. Those present agreed "That the number 0.00 III 8 should be adopted as the number of grams of silver deposited per second from a neutral solution of silver nitrate by a current of I ampere." The specifications of the preceding year were not changed, but were published again in the report of the Nottingham meeting ${ }^{65}$ (1893), which included all the points agreed on by the international gathering at Edinburgh.

The International Electrical Congress ${ }^{66}$ at Chicago in 1893 adopted in its chamber of delegates a resolution defining the international ampere as one-tenth of the cgs ampere and said that it was represented "sufficiently well for practical use by the unvarying current which $* * *$ deposits silver at the rate of 0.00 I I 8 of a gram per second." This definition was accompanied by specifications which were exactly the same as in the report of the

61. This Bulletin, 10, p. 442 .

62 This Bulletin, 11, p. 566 .

${ }^{63}$ B. A., Report for 1891, p. 154 .

${ }^{64}$ B. A., Report for 1892 , p. 135 .

65 B. A., Report for 1893, p. 127 .

${ }^{66}$ Report of congress, pp. I7, 20, 1893; Caast and Geodetic Survey Bulletin 30.

$67154^{\circ}$ - vol $13-16-10$ 
electrical standards committee, but lacked the description of the "method of making a measurement." These are therefore the first international specifications for the voltameter, but their adoption was not obligatory on the countries represented. The countries participating were invited to adopt the recommendations of the congress.

The United States, by an act ${ }^{67}$ approved July I2, I894, was the first to adopt the recommendations of the Chicago congress, although the wording of the act was slightly modified from that of the resolutions adopted by the congress, and the duty of preparing specifications for the use of the voltameter was laid on the National Academy of Sciences. The specifications which they adopted were essentially those of the congress with the "method of making a measurement" of the English electrical standards committee added, but both were slightly modified in wording.

A few weeks later a British order in council, ${ }^{63}$ August 23, I894, adopted the recommendations of the Chicago congress with specifications including the method of making a measurement as previously reported by the electrical standards committee.

A decree ${ }^{69}$ of the President of France April 25, I896, adopted the voltameter for the practical measurement of the ampere with specifications similar to those of the electrical standards committee of the British Board of Trade.

In Germany the law ${ }^{70}$ of June I, I 898, adopted the voltameter and empowered the Bundesrath to fix the conditions under which the silver is to be deposited. The German law differed in some important respects from the resolutions of the Chicago congress. Some other countries also adopted similar laws for the electrical units. The next important step was taken at the Leicester ${ }^{i 1}$ meeting of the British association, where more elaborate specifications were reported as a proposal from the National Physical Laboratory for discussion at the electrical congress at London the following year.

The London congress ${ }^{72}$ made a distinction between the ampere and the international ampere. The latter they defined in terms of the silver roltameter, but the meager specifications adopted represented only the principal points on which there was no difference of opinion, and it was the intention that the international

E7 Coast and Geodetic Surver Bulletin No. 3I; Standards for Electrical Measure, Nat. Acad. Sci., I895.

\& B. A., Report for $1 \& 94$, D. $: 36$.

* This Bulletir, 1, p. 75 , Iga4; Circular No. 60, p. 62, I9I6.

This Builetin, 1, p. 72, Igc4; Circular No. 60, p. 60, I9I6.

I1 B. A., Report for $190^{-}$, p. $; 6$.

is Report of London congress, p. ;2; igos. 
committee should adopt more detailed and rigorous specifications, but this has not yet been done.

The specifications adopted by the London congress are as follows:

\section{SPECIFICATION RELATING TO THE DEPOSITION OF SHVER}

The electrolyte shall consist of a solution of from ${ }_{5}$ to 20 parts by weight of silver nitrate in roo parts of distilled water. The solution must only be used once, and only for so long that not more than 30 per cent of the silver in the solution is deposited.

The anode shall be of silver, and the kathode of platinum. The current density at the anode shall not exceed $\frac{1}{5}$ ampere per square centimetre and at the kathode $\frac{1}{50}$ ampere per square centimetre.

Not less than Ioo cubic centimetres of electrolyte shall be used in a voltameter.

Care must be taken that no particles which may become mechanically detached from the anode shall reach the kathode.

Before weighing, any traces of solution adhering to the kathode must be removed, and the kathode dried.

Dr. Rosa, at the request of the members of the international technical committee, prepared a new set of voltameter specifications, but these were not adopted although published ${ }^{73}$ by the technical committee in its report.

Although the specifications for the voltameter are not yet adopted, Switzerland by Federal law ${ }^{74}$ of June 24, 1909, and England by order in council of January 10, I910, adopted the recommendations of the London conference, and legislation ${ }^{75}$ on this subject had passed the Chamber of Deputies of France prior to the outbreak of the European war. The specifications which we publish below are the outcome of our own work on the voltameter and we hope they will be of service when it is possible for the international committee to adopt specifications.

\section{SPECIFICATIONS PROPOSED BY THE BUREAU OF STANDARDS}

These specifications, which are the outcome of the Bureau's experiments of the past eight years, are prepared for work of the highest precision and must be closely followed when an accuracy of $0.00 \mathrm{I}$ per cent is desired. To attain this degree of precision, the utmost care as to the purity of the materials and in the manipulation of the voltameters is necessary, and the result should be the mean of several separate experiments with two or more voltameters in series in each experiment.

For work requiring only o.or per cent accuracy, the precautions taken may be somewhat reduced. The labor of weighing the deposits and purifying the salt may be considerably lessened as

\footnotetext{
73 Report of Int. Tech. Com., p. 199; г9r2. ${ }^{11}$ Circular No. 60, p.63; 19r6. ${ }^{75}$ Circular No. 60, p. 57; 1916.
} 
compared with the procedure for work of the highest accuracy, provided the unpurified electrolyte does not contain more than 25 parts in I 000 o00 of acid, or enough alkali to produce striation. No observations should be used in which the deposits show striations. The mean of several deposits should be taken.

For work requiring only O.I per cent accuracy, the c. p. silver nitrate, prepared by the best manufacturing chemists, may be used without further purification. Filter paper in minimum amounts may be used as a septum between anode and cathode, for convenience, if desired. The deposits will then be striated, but deposits showing excessive striations of a leaden color should not be relied on. With careful manipulation, the mean of two deposits should give results of the desired accuracy.

THE SPECIPICATIONS.*

I. The electrolyte shall consist of a solution of silver nitrate in distilled water (I), having from Io to $20 \mathrm{~g}$ (2) of silver nitrate in Ioo $\mathrm{cc}$ of the solution.

2. The electrolyte must be free from organic or other reducing substances and colloids, as shown (a) by a suitable chemical test (3), (b) by giving a crystalline deposit free from striations (4), and (c) by giving the same weight of a deposit in a large and in a small voltameter (5).

3. The silver nitrate may be purified by crystallization from acid solution and fusion, and if the chemical test for purity is omitted, it should be purified until further crystallization from acid solution and subsequent fusion does not change the weight of the deposit (6).

4. The voltameter should contain not less than $75 \mathrm{cc}$ in the cathode chamber (7), and the deposit should not continue long enough to reduce the concentration of the electrolyte at the surface of the cathode chamber below 5 per cent (8).

5. The electrolyte when ready for use must be neutral or slightly acid, as tested by methyl red or iodeosin (9). As I part in I 000000 of base may increase (Io) the deposit appreciably, it may be better to have a slight acidity (say I part in I 000 ooo) than to take the risk of making it slightly basic in attempting to make it strictly neutral. The electrolyte must be neutral at the end of the experiment, or, if not, only a trace of acid or base should be present. Any septum or other substance which contaminates the electrolyte, or makes it basic, or produces more than a trace of acid must be avoided (I I). 
6. The cathode is most conveniently a crucible or bowl, preferably of platinum (although gold (I2) may be used), of from I 25 to 400 cc capacity (I3). The surface should preferably be smooth and bright, and the deposited silver should be removed each time by electrolysis (I4) or by acid without scratching or marring the surface of the platinum by any instrument.

7. The anode should be of pure silver and is preferably (I5) coated with electrolytic silver (I6). The anode should have as large an active area as the size and type of voltameter permit (I7).

8. The current during a deposit should be maintained constant, and is preferably not more than I ampere, and the time not less than one hour (I8).

9. If the surface of the platinum is perfectly clean and the electrolyte pure, the silver will be adherent and there will be little, if any, loose silver (19). After thorough washing (20), the cathode bowls are dried at about $150^{\circ} \mathrm{C}$, preferably in an electric oven, and after cooling are weighed (2I). In the weighing a similar platinum dish, adjusted to the same weight, is advantageously used as a tare.

10. The electromotive force of the standard cell employed is calculated from the weight of silver deposited (22), the resistance (23), and the time (24), using I.I I $800 \mathrm{mg}$ per coulomb (25) as the electrochemical equivalent of silver (26).

II. If a septum between the anode and cathode is used (27), it must not contaminate the electrolyte with organic or reducing impurities (28); it must not produce acid or alkali in the electrolyte (29); and it must be of sufficiently fine grain to hold back the anode slime without introducing any high resistance into the voltameter (30).

\section{SUPPLEMENTARY NOTES}

I. The water should be of the best quality and free from $\mathrm{CO}_{2}$. It should not be more than $\mathrm{I} \times \mathrm{IO}^{-6}$ alkaline or acid, and its conductivity should not be more than $2 \times 1 \mathrm{IO}^{-6}$ reciprocal ohms (resistance 500 ooo ohms per cubic centimeter). The water and electrolyte should be kept in bottles of insoluble glass. A bottle long used for the purpose is much better than a new one. The electrolyte should not be stored in glass vessels for long periods, but fused solid $\mathrm{AgNO}_{3}$ may be preserved indefinitely.

2. The lower limit of concentration is safe and economical for cathode current densities up to o.or ampere per square centimeter. Higher concentrations are useful for large current densities and 
for small voltameters, in which convection currents can not replenish the impoverished liquid at the cathode as freely as in the large voltameters.

3. This test is for reducing impurities, and consists in adding $\mathrm{N} / 1000 \mathrm{KMnO}_{4}$ solution (I cc at a time) to ro cc of a 66 per cent solution of the $\mathrm{AgNO}_{3}$ (acidified) until the color persists for five minutes. It is described in volume 9, page 53I.

4. A deposit made from pure electrolyte presents a white matte surface, and under the microscope is seen to be made up of crystals having mirror-like faces and sharp angles. When impurities which increase the mass of deposit by 2 to 5 parts in 10000 are present, the crystals become very irregular and the deposit appears striated. For excessive amounts of impurities the crystalline structure vanishes, the striations become very prominent, and the color of the deposit is often gray or yellowish.

5. Heavier deposits are obtained in large voltameters than in small voltameters if reducing impurities are present in the electrolyte. The agreement of two different sizes is one criterion for the purity of the electrolyte, and is particularly useful if any colloids have escaped detection by the permanganate test.

6. The purest $\mathrm{AgNO}_{3}$ purchased from the best manufacturing chemists may be used in some cases for work requiring o.or per cent accuracy (providing there is no striation and no appreciable volume effect), but, in general, this is not the case and it can not be depended upon to be sufficiently good for the most precise work. The means used to further purify it are somerhat dependent on the nature and amount of impurities that it contains. In most cases a preliminary fusion of the crystals (slightly acidified with $\mathrm{HNO}_{3}$ ) serves to oxidize the organic impurities. Colloidal silver and some other impurities appear to collect at the surface and may be partially removed after the salt has solidified by washing the surface or by filtration. If the salt is now pearl white, one recrystallization from acid solution and fusion (care being taken not to overheat the salt and thereby expel the last trace of acid) will usually complete the purification. Some of the mother liquor should always be tested for turbidity by greatly diluting it with distilled water, since chlorides, sulphides, and some other substances which are, relatively speaking, soluble, in concentrated silver nitrate might otherwise escape detection. Before making up the electrolyte the surface of the fused cake should be again washed. The fusions may be made in a platinum dish, which should be 
lifted out of the furnace as soon as the last trace of solid salt has melted.

7. When a porous-cup voltameter is used, the cathode chamber is that space occupied by the electrolyte outside of the porous cup. When a nonseptum voltameter (Smith's form) is used, the cathode chamber means the space outside of the glass parts when the latter are closed, as before or after an experiment.

8. The concentration in the electrolyte in contact with the cathode is much reduced during the deposit. If the electrolyte becomes too impoverished at the cathode, the fall of potential at the cathode may be increased sufficiently to liberate hydrogen, and a slimy deposit of silver is then obtained which does not accurately represent the quantity of electricity that has passed through the voltameter as computed from the electrochemical equivalent of silver and can not be accurately weighed. The electrolyte may become turbid, due to finely divided silver in suspension.

9. The iodeosin (Io mg per liter) is dissolved in ether and kept over a layer of water. Before adding $2 \mathrm{cc}$ of the ether solution of the indicator to Io $\mathrm{cc}$ of the $\mathrm{AgNO}_{3}$ solution the $\mathrm{Ag}$ must be precipitated as $\mathrm{AgCl}$ by neutral $\mathrm{KCl}$ and filtered off. The acid or base that the filtrate contains is then determined by titration, using $\mathrm{N} / \mathrm{ro00}, \mathrm{H}_{2} \mathrm{SO}_{4}$, or $\mathrm{NaOH}$ as required. This test is described in volume 9, page 526 . The methyl-red indicator is a 0.2 per cent solution of methyl red in alcohol. One drop or two, at the most, is added to the filtrate and the titration made as described above.

IO. When the base (AgOH) has been produced by overfusion of silver nitrate or by the addition of other hydroxides, it is usually in the colloidal state and will slightly increase the weight of the deposit. Acid in pure electrolyte tends to decrease the deposit slightly; I part of acid in I 000000 parts of electrolyte produces about $4 \frac{T}{2}$ parts in $I 000000$ difference in deposit on the average. Above ro parts of acid in I 000000 the effect is proportionally slightly less.

I I. Filter paper at first renders the $\mathrm{AgNO}_{3}$ solution basic, owing to the basic reaction of the oxycellulose and cellulose hydrates, but later, owing to the reducing action on the $\mathrm{AgNO}_{3}$, the solution becomes acid. Raw silk when first used acts similarly to filter paper, but later yields a small amount of acid, which renders the $\mathrm{AgNO}_{3}$ solution slightly acid without the precipitation of silver. This is further explained in the Report of the International Technical Committee, page I 74 . 
I2. Platinum is preferable to gold because it is more durable. There appears to be no difference in weight between deposits made on gold and platinum.

I3. The errors due to manipulation increase where sizes larger or smaller than these limits are used. The provisional specifications of the London conference provide that the current density at the cathode shall not exceed I/50 ampere per square centimeter. It seems best, now, that this should be changed to I/I00 ampere per square centimeter, particularly if the concentration of electrolyte is $10 \mathrm{~g}$ of salt in IOO cc of solution.

I4. This is most conveniently done by allowing a small current to flow through the voltameter overnight or until the silver has all been remored.

I5. More anode slime is formed on bare silver anodes than on those coated with electrolytic silver. In voltameters without septum this may cause trouble if the slime escapes from the glass trap arranged to confine it.

I6. This is conveniently done when a previous deposit is being removed from the cathode bowl, using a relatively small current. Before use the anode should be heated to $200^{\circ}$ or more to expel any acid that may have come from the solution.

I7. The trouble with anode slime is greatly reduced by increasing the size of the anode. The provisional specifications of the London conference provide that the current density shall not exceed $1 / 5$ ampere per square centimeter. This is allowable, but it is better to have the current density much smaller. Electrolytic silver increases the active area of the anode considerably over what the same anode would have if bare.

IS. Before starting the current through the voltameters, it is desirable to estimate as nearly as possible the resistance of the voltameters, and adjust the total resistance so that the current will start at its correct value as closely as possible. It is essential to have means of quickly adjusting the current to the precise value, and also a convenient adjustment to counterbalance the drift or fluctuations in the current during the progress of the experiment.

19. Any loose silver drawn off in the electrolyte or wash waters should be carefully saved and added to the bowl before weighing the deposit.

20. The deposits should be washed only with pure distilled water, which should be tested occasionally for $\mathrm{AgNO}_{3}$ with $\mathrm{KBr}$ as it is drawn off. By this means I or 2 parts in 100000 of the 
silver salt can easily be detected. A more sensitive method, however, is to make conductivity measurements of the water after drawing it off for comparison with its initial conductivity. Several wash waters should be used after no $\mathrm{AgNO}_{3}$ can be detected by $\mathrm{KBr}$ in the liquid drawn off. The washings, which are usually five to seven in number for each cathode, should be done without delay. It is not advisable to soak the deposits in water overnight. When washing the bare platinum bowl preparatory to an experiment, acids and alkalies may be used. After the bowl has been prepared for weighing preliminary to the deposit, it should not be touched with the bare hand until the whole experiment has been completed.

21. In making the weighings, care must be exercised to protect the bowls and balance from even very slight changes in temperature. The bowls should be in perfect equilibrium with the temperature and humidity of the balance case.

22. The weight of silver (corrected to vacuo) is expressed in milligrams.

23. The resistance of the standard across the terminals of which the drop is potential is made equal to the voltage of the cell to be measured, is expressed in international ohms.

24. The time is expressed in mean solar seconds and should be recorded on a chronograph. The timing circuit should not be electrically connected to the voltameter circuit, owing to the possibility of leakage currents affecting the mass of silver deposited.

25. This is according to the decision of the London conference.

26. $\operatorname{Emf}=\frac{\text { weight of deposit } \times \text { resistance }}{\text { I.I I } 800 \times \text { time }}$

27. The function of a septum between the anode and cathode is to prevent the slime formed on the anode during electrolysis from reaching the cathode. A porous cup of pukal ware is useful for this purpose, when it is properly prepared. If no septum is used, a suitable and efficient glass trap to catch the slime must be provided.

28. This occurs when filter paper, silk, blotting paper, and similar substances are used.

29. These effects are also produced by the materials mentioned above (28) and by the porous cup if not properly prepared. The free alkali of the porous material should be eliminated by filtering dilute $\mathrm{HNO}_{3}$ and water through the pores, followed by several portions of the best $\mathrm{AgNO}_{3}$. The pores should be completely 
filled with electrolyte before use. Between experiments the cups should be kept immersed in the best electrolyte. The porous cups become stained with use, but this does not seriously affect the results obtained with them. They may be whitened by filtering strong (not concentrated) $\mathrm{HNO}_{3}$ through the pores, which, however, must be completely washed out with water before saturating the pores with the neutral $\mathrm{AgNO}_{3}$ preparatory to use in the voltameter. Satisfactory cups for the purpose are made of pukal ware, and are about $60 \mathrm{~mm}$ high, $35 \mathrm{~mm}$ diameter, and I mm thick, as manufactured by the Koniglich Porzellan Manufaktur in Berlin and by John Maddock, Trenton, N. J.

30. The resistance of the septum should preferably not exceed 2 ohms.

Washington, April 5, I9I6. 


\section{A P P E N D I X E S}

\section{Appendis A.-BIBLIOGRAPHY OF THE SILVER VOLTAMETER WITH A FEW PAPERS ON CLOSELY ALLIED SUBJECTS}

During the progress of the Bureau's work on the silver voltameter a considerable file of references to papers bearing on the voltameter has been accumulated. From this file the following bibliography has been compiled. Although a number of previous papers on the silver voltameter have contained reviews of the literature, we have not found in any of these as complete a list as we append below. We believe that it contains all of the principal papers dealing with the silver voltameter. In addition, we have included a number of papers in which the silver voltameter was used for measuring the electric current in the course of investigations on other subjects. We have also included a few papers not dealing specifically with the silver voltameter, but on closely allied topics. Such papers are on the following subjects: Various forms in which silver is deposited, properties of silver-nitrate solutions; the formation of silver peroxynitrate; the ratio of the atomic weights of silver and iodine; the validity of Faraday's laws; the definition of the fundamental electrical units; and a few papers of historical interest dealing with the beginnings of voltametric measurements.

The papers are arranged alphabetically, according to the name of the author. We have indicated the title or subject of the paper in English, but we have not given the exact title in every case. This is because references to reports of institutions, etc., are usually to paragraphs without formal titles, or, on the contrary, some papers have titles that are excessively long, while in still other cases the title does not convey an idea of our particular interest in the paper. In general, however, we have given the exact title. The references are given with the usual abbreviations, and we think they will readily be understood without the necessity of listing the full names of the journals as a key to the abbreviations. We have not included any references to the voltameter from compendiums of physics (except one case of historical interest), encyclopedias, handbooks of engineering, or textbooks. It is rather surprising, however, to find how crude and inaccurate many of these descriptions are. In the index of the last edition of one of the largest and best-known encyclopedias it is surprising to read "Voltameter, see Voltmeter." 
Bibliography

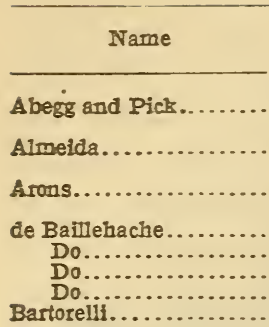

Bates and Vinal..

Baümler.

Berder.

Do.

Beach.

Behn....................

Betts.

Betts and Kern...........

Board of Trade..........

Title or subject

Influence of silver nitrate on the solubility of silver nitrite.

Decomposition of salts dissolved in water.

Determination of the Verdet constant..

Electrical units.

Fixing the units by legislation.........

The silver voltameter...................

Electrical units and French legislation.

On the behavior of a voltameter with platinum electrodes.

Comparison of the silver and iodine voltameters and the determination of the Faraday.

Separation of energy losses in the voltameter.

On the atomic weights of silver and iodine.

A revision of the atomic weights of silver and iodine.

On the copper voltameter.............. On the striated arrangement of galvanic deposits.

Phenomena of metal depositing

The lead voltameter...................

Reports of electrical standards committee dealing with vo!tameter specifications.

Boerema

Boltzmann

Do.

Electromotive force of the Weston cell in intermational units.

Researches on the silver voltameter...

Historical review of the electrical units, their definitions and the international standards.

Bose.

Bose and Conrat.

British Assoc. Report

No. 38 .

Buckner and Hulett...

Bundesrath.

Bureau of Standards...

$$
\text { Do. }
$$

Do.

Carhart.

Do ................

Carhart, Willard, and Henderson.

Cohen.

Dahr.

Danneel.

Danneel .............

Dede...........

Duschak and Hulett...

Dellinger.

Ediund

Egoroff.

Electricus (pseud)...... Eisenreich.

von Ettingshausen..... Baraday.................

Farup

A silver microvoltameter

Experiments on septa for the............

Studies on the silver coulometer......

Regulations issued by the Bundesrath for the use of the silver voltameter.

Announcement of a change in the value of the international volt.

The silver voltameter.

Electrical units and standards.

Electromotive force of a Daniell cell. Report of committee on standards of measurement.

A new electrolyte for the silver voltam. eter.

Validity of Faraday's law at high pressures.

Inaceuracies in the copper voltameter. On the electrolytic separation of metals. Accuracy of the copper voltameter..... On the copper voltameter.............. Studies on the silver coulometer......

The international system of electric and magnetic units.

Researches on the heat changes at the poles of a voltameter.

Preliminary work of preparing the standards of the primary electrical units.

Priority claim for the invention of the voltameter.

On the use of silver-fiuoride solution in the silver coulometer.

On the Clark cell....................

First voltameter.

On a new silver roltameter
Reference

Ber. Deut. Chem. Gesel., 38, p. 2571; 1905.

Ann. d. Chim, et Phys., III, 51, p. 257; 1857.

Wied. Ann., 24, p. 161; 1885.

1909.

Rev. Gen. Sci., 24, D. 17; 1913.

Lumiere Electr., 22, p. 44; 1913.

Electr., 75, p. $56 ; 1915$.

Phys. Zs. 4, p. 350; 1904.

J. Am. Chem. Soc., 36, p. 916; 1914.

Zs. f. Elektrochem., 12, p. 481; 1906.

Camegie Publication No. 135.

J. Am, Chem. Soc., 32, p. 1591; 1910.

Am. J. Sci., 46, p. 81; 1893.

Wied. Ann., 51, p. 105; 1894.

Trans. Am. Electrochem. Soc., 8, p. 63. Trans. Int. Elec. Cong., St. Louis, 2 p. 67, 1904; Electr., 54, p. 16, 1904; Metall., 1, p. 430, 1904.

B. A. Reports for 1891 , p. 154; for 1892 p. 135; for 1893, p. 127; for 1894, p. 136; for 1907, p. 77; Electrician, 27, p. 325, 1891. A.I. E. E. 10, p. 17, 1893 .

Arch. Neer. Sci., 3, p. 336; 1914.

Sitzber. Akad. Sci., Wien., IIA, 121, p. $1051 ; 1912$.

Sep. A bdruck. Mit. des K. K. Versuch. II, pts. 3 and 4; 1913.

Chem. Zeit., 26, pp. 47 and 66; 1902. Zs. f. Elektrochem., 14, p. 86; 1908. Portsmouth Meeting, p. 82; 1911.

Trans. Am. Electrochem. Soc., 22, p. 367; Int. Cong. App. Chem., 26, p. $565 ; 1912$.

Zs. f. Instrk., 21, p. 180; 1901.

Bu. Stđs. Circular No. 29; 1910.

Annual Report, Director of Bu. Stds., p. 47; 1915.

Bu. Stdds. Circular No. 60; 1916.

Am. J. Sci., 28, p. 374; 1884.

Proc. A. A. A. Sci., p. 71; 1900.

Trans. Am. Electrochem. Soc., 9, p. 375; Phys. Rev., 23, p. 189; 1906.

Zs. f. Phys. Chem., 84, p. 83; 1913.

Zs. f. Elektrochem., 19, p. 746; 1913.

Zs. f. Elektrochem., 4. p. 154; 1897.

J. Am. Chem. Soc., 38, p. 1156, 1916. Zs. f. Elektrochem., 17, p. 238; 1911. Trans. Aro. Electrochem. Soc., 12, p. 257; 1907.

Bull. Bu. Stds., Sci. paper No. 292. (In press.)

Wied. Ang., 19, p. 287; 1883.

Rep. Bureau Wts. and Meas., Petrograd, p. 122; 1911.

Sturgeon's Ann. of Elec., 1, p. 505; 1836.

Zs. f. Phys. Chem., 76, p. 643; 1911.

Zs. f. Elektrotech., 2, p. 484; 1884.

Exper. Researches, 1, p. 217, 1834:

Phil. Trans., p. 91, 1834.

Zs. E. Elektrochem., 8, p. 569, 1902. 
Bibliography-Continued

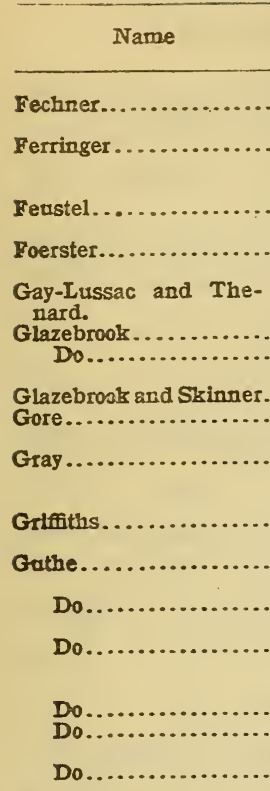

Eaga and Boerema....

Henderson

Eering.

Do.

Do.

Eerroun

Eughes and Withrow.

Enilett and Vinal.

International Conference on Electrical Units.

International Electrical Congress.

Do

International Technical Committee.

Jaeger.

Jaeger and Lindeck

Jaeger and von Steinwehr.

Do..

Do.

Do.....

Jaeger, Iindeck, and von Steinwehr.

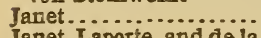

Janet, Laporte, and de la Gorce.

Kahle.

Do
Electrochemical remarkableness of silver nitrate.

Determination of the international ampere and volt by the silver voltameter and Weston cell.

On voltameters with and without silk (activities of the Reichsanstalt).

On the copper voltameter.

Early experiments in electrochemical decomposition.

Electromotive force of standard cells.. The ohm, the ampere, and the volt, 1862-1912.

On the Clark cell.

Electrolytic balance of chemical cor sion.

On the electrolysis of silver and copper and the standardization of electric meters.

Errors in electrical units affecting the mechanical equivalent of heat.

Determination of electrical units by an absolute electrodynamometer.

A study of the silver voltameter.......

The silver voltameter

The silver coulometer

Absolute electromotive force of standard cells.

Electrochemical equivalent of silver..

Electromotive force of Weston normal cells.

Thermoelectric behavior of silver (electrochemical paper).

Table of electrochemical equivalents and their derivatives with examples. Uniformity in electrochemical equivalents.

Remarks on effect of gas in voltameter cathodes.

An iodine voltameter.

Remarks on originality of Faraday's voltameter.

Character of silver deposits from various electrolytes.

Studies on the silver voltameter .......

Report

.....do

.... do.

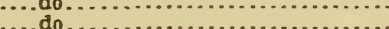

Electrical standards.

Silver voltameter (activities of the

Reichsanstalt)

Investigation of the silver voltameter. .

Silver voltameter (activities of the Reichsanstalt).

Remarks on the silver voltameter....

On the inclusion of electrolyte in the silver deposits and the volume effect. The silver voltameter (activities of the Reichsanstalt).

Electrical units.

Electrochemical equivalent of silver..

On the Clark cell

Silver voltameter (activitles of the Reichsanstalt).
Reference

Pogg. Ann., 47, p. 1, 1839.

Electritchestvo 35, 13, p. 260, 1914.

Zs. f. Instrk., 30, p. 115, 1910.

Zs. f. Elektrochem., 3, p. 493, 1896.

Recherches Physico-Cnimiques, 1, $12,1811$.

Nature, 85, p. 508, 1911.

J. Inst. E1. Eng., 50, p. 560; Electr., 70. p. 1014; 1913.

Phil. Trans., 183 A, D. 567; 1892

Nature, 27, p. 326; 1883.

Phil. Mag., 22, p. 389; 1886.

Nature, 56, p. 259; 1897.

Phys. Zs., 1, p. 235; 1900 .

Bull. Bu. of Stds., 1, p. 21, 1904; Phgs. Rev., 18, p. 445; 19, p. 138, 1904

Trans. Int. El. Cong., St. Louis, 2, D. 96; Trans. Am. Electrochem. Soc., 6, p. 96; 1904.

Bull. Bu. of Stds., 1, p. 349; 1905.

Bull. Bu. of Stds., 2, p. 33; 1906.

Ann. d. Phys., 20, p. 429; 1906.

Arch. Neer. Sci., IIIa, 3, p. 324; 1914.

Phys. Rev., 23, p. 101; 1906.

Electrochem. Ind., 1, p. 170; 1903.

Trans. Am. Electrochem. Soc., 3, p. 291; 1903.

Trans. Am. Electrochem. Soc., 12, p. 293; 1907

Phil. Mag., 40, p. 91; 1895.

Proc. Lond. Elec. Soc., p. 135; 1837.

J. Am. Chem. Soc., 32, p. 1571; 1910.

Bull. Bu. of Stds., 11, p. 553, 1914; J. Wash. Acad. Sci., 4, p. 593, 1914; J. Phys. Chem., 19, p. 173, 1915.

Charlottenburg, 1905 (Gedruckt in dem Reichsdruckerei 1906).

Chicago, 1893.

London, 1908.

Washington, 1910; report published 1912.

Trans. Int. Cong., St. Louis, 1, p. 331; 1904.

Zs. f. Instrk., 26, pp. 122 and 157; 1906.

Zs. f. Instrk., 28, pp. 327, 353; 1908.

Zs. f. Instrk., 29, p. 114; 1909.

Elektrotech. Zs., 35, p. 819; 1914.

Zs. f. Instrk., 35, p. 225; 1915.

Zs. f. Instrk., 28, p. 112; 1908.

Bull. Int. Soc. Electr., 3, p. 950; 1913.

Bull. Int. Soc. Electr., 8, p. 523; Trav.

Lab. Centr. d'Elec., 2, p. 288, 1908.

Zs. f. Instrk., 12, p. 117; B. A. Report for 1892, p. 148; Elektrotech. Zs., 13, p. $407,1892$.

Zs. f. Instrk., 16, p. 215, 1896; 17, p. 145 . 1897; 19, p. 212, 1899. 
Bibliography-Continued

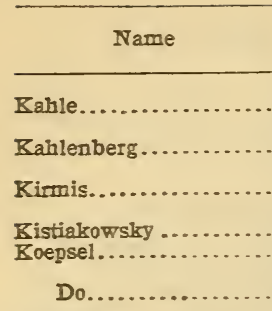

Kohlrausch.

Do..

Title or subject

Silver voltameter

Electrodeposition of metals from nonaqueous solvents.

On the forns of electrclytically ceposited silver.

Silver titration voltameter.............

Constant of electromagnetic rotation of polarized light.

Determination of the electrochemical equivalent of silver.

On the electrochemical equivalent of silver.

On determinations of F. and W. Koinlrausch with reference to the anode

liquid.

Kohlrausch, F.and W..

reliminary communication of results on electrochemical equivalent of silver.

Do...............

Kohlrausch and W'ebez.

Kohlschutter and Schacht.

Bohlschutter and Toro-

poff.

Kreider.

Laird and Hulett.

Do..

Laporte and de la Gorce.

Leduc................ Do..................

Do.

Do.

Do

Lewis. On the

Electroche

perature.

Forms of deposited metal-III. Infiuence of foreign substances.

Forms of deposited metal-I. Black silver.

On the atomic weight of iodine......

Iodine titration voltameter ............

Inclusions in electrolytic silver and their effect on the electrochemical equivalent.

Electrochemical equivalent of cadmium

On the electrochemical equivalent of silver.

On the electrolysis of silver nitrate... Electrochemical equivalent of silver, copper, and water.

Electrolysis of silver nitrate.

On the electrochemical equivalent of silver.

Electrolysis of a mixture of salts

Silver-bromide voltameter...

The silver poitameter-Part III. The solvent properties of silver gitrate.

McDanie

Mascart.

Do.

Do.

Mather and Smith.

Mathers and German. Mendeninall............

Merrill

Minet............................. Miscellaneous $\mathrm{N}_{\text {otes }}$ and Discussions.

Do..............

Do.....................

Do.....

Do

Do.................

Do.................

Do...

hemistry of the silver voltameter

On the absolute measurement of current by electrolysis.

On the electrochemical equivalent of water.

On the electrochemical equivalent of silver.

A comparison of the Board of Trade ampere balance with that at the N. P. L.

Iercurous perchiorate voltametez .... Legal units of electric meastrie........

influence of temperature, pressure, etc, on deposits of silver voltameters. Study of the voltameter as a standard. Referring particularly to Vaz Dijk's work.

On Faraday's law

On the lead and silver voltameters...

Importance of the electrochemical equivalent and various determinations of it.

Review of the roltameter situation....

The silver voltameter.

Final resuits with the silver voltameter. On the silver voltameter............. Silver and iodine voltameters..

Mulder and Heringa.

Silver peroxvnitrate.

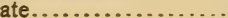

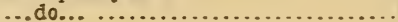

Reference

Zs. f. Insirk., 18, pp. 229 and 267, 1898; Wied. Ant., 67, p. 1, 1899.

J. Phys. Chem., 4, p. 349; 1900.

Pogg. Ann., 158, p. 121; 1876.

Zs. Elektrochem., 12, p. 713; 1906. Wied. Ann., 26, p. 476; 1885.

Fied. Ann., 31. p. 268; 1887.

Pogg. Ann., 149, p. 170; 1873.

Ann. d. Physs., 25, p. 580; 1908.

Sitzber d. Phys.-Med. Gese1., Wïrtzburg, p. $41 ; 1884$.

Wied. Ann., 27, p. 1; 1886.

Ann. d. Phys., 25, o. 409; Deut. Phys. Gesel., 9, p. 681, 1907.

Zs. f. Elekrtiochem., 19, p. 172; 1913.

Zs. f. Elektrochem, 19, p. 161; 1913.

Lieb. Ann. d. Chem., 337, pp. 123, 362 ; 1904.

Am. J. Sci., 20, p. 1; 1905.

Trans. Am. Electrochem. Soc. 22, p. 345; Int. Cong. App. Chem., 26, p. 599,1912

Trans. Am. Electrochem. Soc., 22, p. $385 ; 1912$.

Trav.Lab. Cent. d'Elec., 2, p.318; Bull. Int. Soc. Electr., 10, p. 157; C. R., 150, D. $278,1910$.

Electrochemie, 3, p. 151.

Rapp. Cong. Int. de Phys., Paris, 2, p. $440 ; 1900$.

J. d. Plyss., 1, p. 561, 1902; C. R., 135,

C. $R, 23,1902$. 135, p. 237; Electrochem., 8, p. C. R. 135 , p. 237 ; Electrochem., 8, p.
127,1902 ; Electricien, 24, p. 132,1902 . C. R., 135, p. 395; 1902.

J. Am. Chem. Soc., 31, p. 1145; 1909.

Proc. R. S., 91, p. 53; 1914.

Science, 34, pp. 32, 159; 1911.

C. R., 93, p. 50; 1881.

J. d. Phys., 1, p. 109; 1882.

J. d. Phys., 3, p. 283; 1834.

Proc. R. S., 80, p. 383; 1908.

Izd. Univ. Stud, p. 41; 1910.

Science, 1, p. 9, 1895; Coast and Geodetic Survey Bulletins Nos. 30 and 31; Coast and Geodetic Survey Report for 1893, part 2, appendix 7, p. 173.

Phys. Rev., 10, F. 167; 1900.

Lumiere Electr., 22, p. 49 ; 1886. Electr., 52, p. 613; 1903.

Electrochem. Ind., 1, p. 153; 1903.

Electr., 54, p. 43; 1904 .

Electrochem. Ind., 2, p. 116; 1904.

Electrochem. Ind., 2, p. 288; 1904.

Electr. World, 60 , p. 1243,$1912 ; 63$, p. $350,1914$.

Electr. Rev., 62, p. 890; 1913.

Electr. Rev, 62, p. 886; 1913.

Elect. World, 64, p. 454; 1914.

Rec. Trav. Chim., 17, p. 129; 1898.

Rec. Trav. Chim., 15, p. 1; 1896. 


\section{Bibliography-Continued}

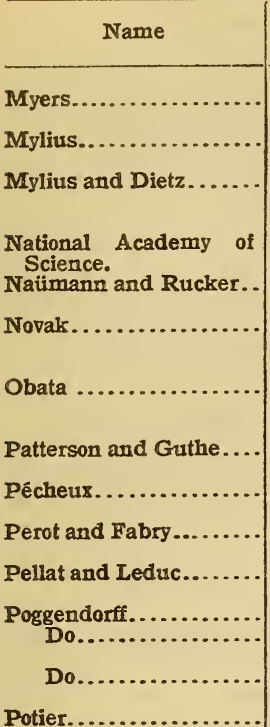

Potier and Pellat.

Rayleigh

Do.

Rayleigh and Sedgwick. Do...

Richards............... Richards and Anderegg. Do

$$
\text { Do }
$$

Richards, Collins, and Heimrod.

Richards and Forbes. Richards and Heimrod.

Richards and Stull...... Riesenfeld .............. Rodger and Watson.... Rosa..................

Rosa, Dorsey, and Miller.

Rosa and Vinal.........

Do

Rosa, Vinal, and $\mathrm{MC}-$ Daniel.

Do.

Do

Do

Rosa and Wolff.

Schuster and Crossley.. Shaw...... Crossey.

Do
On the influence of dissolved gases on the silver voltameter.

The silver voltameter (Activities of the Reichsanstalt).

On the purity of silver for anodes (Activities of the Reichsanstalt).

Standards for electrical measure .....

Influence of silver nitrate on the solubility of silver nitrite.

Studies on the silver voltameter........

The silver voltameter

A new determination of the electrochemical equivalent of silver.

Determination of certain atomic weights by voltameter methods.

Measurement of Clark cells in international volts.

Determination of the electrochemical equivalent of silver.

First silver voltameter.................

First use of a porous cup in a silver voltameter.

An early illustration of Poggendorff's voltameter.

On the electrochemical measure of the intensity of electric currents. Electrochemical equivalent of silver...

On the absolute measurement of current.

On the accuracy of voltameter measurements.

On the electrochemical equivalent of silver.

Note con................................

Inclusions in the silver voltameter deposits.

Complications at the anode of the silver voltameter.

Note on Inclusions

Electrochemical equivalents of copper and silver.

Quantitative synthesis of silver nitrate On the accuracy of the improved voltameter.

Validity of Faraday's law

Gas voltameters with nickel electrodes.

Magnetic rotation of polarized light.... tional electrical standard.

International ampere in absolute measure.

The silver voltameter, Part I

The volume effect in the silver voltameter.

Effect of filter paper on the mass and form of deposit in silver voltameter. The silver voltameter, Part II.........

The silver voltameter, Part III.

The silver voltameter, Part IV.

Work of the international technical committee.

Electrolysis of silver nitrate in vacuo.

Verification of Faraday's law with reference to silver and copper.

On the atomic weights of silver and copper.
Reference

Wied. Ann. 55, p. 288; 1895.

Zs. f. Instrk., 22, p. 155; 1902.

Zs. f. Instrk., 21, p. 151; 1902.

Judd and Detweiler, Washington: 1895.

Ber. Deut. Chem. Gesel., 38, p. 2292; 1905.

Proc. Roy. Boh. Acad. Sci., Prague, 1 , p. 387; 1892.

Proc. Tokyo Math. Phys. Soc., II, 8, p. 437, 1916.

Phys. Rev., 7, p. 257; Proc. A. A. A. Sci., 47, p. 155; 1898.

C. R., 154, p. 1419; 1912.

Ann. de Fac. Sci., Marseille, 8, p. 201; 1898.

C. R., 136, p. 1649; 1903.

Pogg. Ann., 70, p. 181; 1847.

Pogg. Ann., 75, p. 337; 1848.

Wied. Galv., 1st ed., 1, p. 314; 1861.

C. R., 108, p. 396; 1889.

J. d. Phys., 9, p. 381; 1890.

Proc. Camb. Phil. Soc., V, p. 50; 1883. Nature, 56, p. 292; 1897.

Proc. R. S., 36, p. 448; 37, p. 142; 1884.

Phil. Trans., 175 A, p. 411; 1884

Proc. Am. Acad. Sci., 44, p. 91; 1908.

J. Am. Chem. Soc., 37, p. 7; 1915

Chem. News, 112, pp. 172, 181, 1915.

J. Am. Chem. Soc., 37, p. 675; 1915

J. Am. Chem. Soc., Oct., 1916.

Proc. Am. Acad. Sci.o, 35, p. 123, 1899,

Zs. f. Phys. Chem., 32, p 321; 1900.

J. Am. Chem. Soc., 29, p. 808; 1907.

Proc. Am. Acad. Sci., 37, p. 415; Zs. l. Phys. Chem., 41, p. 302; 1902.

Zs. f. Phys. Chem., 42, p. 621; 1902.

Zs. f. Elektrochem., 12, p. 621; 1906.

Phil. Trans., 186A, p. 630; 1895

Science, 34, p. 32; 1911.

Bull. Bu. of Stds., 8, p. 367.

Bull. Bu. of Stds., 9, p. 151; J. Wash Acad. Sci., 2, p. 451; Elec. World, 60 , p. 1261, 1912; Elektrotech. Zs., 34, p. 232, 1913.

Bull. Bu. of Stds., 13, p. 447; 1916.

Phys. Rev., 30, p. 658; 1910.

Bull. Bu. of Stds., 9, p. 209; J. Wash. Acad. Scl., 2, p. 509; Elec. World, 60, p. 1252, 1912; Elektrotech. ZS., 34, D. 233, 1913.

Bull. Bu. of Stais., 9, p. 493; J. Wash Acad. Sci., 3, p. 40; Elec. W orld, 60 , p. 84, 1913; Elektrotech. Zs., 34, p. $1168,1913$.

Bull. Bu. of Stds., 10, p. 475; J. Wash. Acad. Sci., 4, p. 52; Elec. World, 63, p. 373, 1914; Elektrotech. Zs., 35, p. $789,1914$.

J. Wash. Acad. Sci., 2, p. 259; 1912.

Proc. R. S., 50, p. 344; 1892.

B. A. Report for 1886, p. 318.

Phil. Mag., 23, p. 138; 1887. 


\section{Bibliography-Continued}

\begin{tabular}{|c|c|c|}
\hline Name & Title or subject & Reierence \\
\hline $\begin{array}{l}\text { Shrimpton.. } \\
\text { Skinner.... }\end{array}$ & $\begin{array}{l}\text { a the atomic weight of copper......... } \\
\text { mrarison of voltameters containing }\end{array}$ & $\begin{array}{l}\text { Proc. Lond. Phys. Soc, 26, p. 292; } 1914 . \\
\text { B. A. Report for 1901, Appendix to No. }\end{array}$ \\
\hline 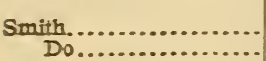 & $\begin{array}{l}\text { ts. } \\
\text { the silver voltameter. } \\
\text { s for electrical meas- }\end{array}$ & $\begin{array}{l}\text { D. } 601 . \\
\text { f. for } 1906, \text { p. } 27 .\end{array}$ \\
\hline Do & $\begin{array}{l}\text { roltameter..................... } \\
\text { son of salt from different }\end{array}$ & $\begin{array}{l}\text { 4, p. 389; 1908. } \\
\text { Rev. Gen. Sci.,19, p. 171; } 1908 \text {. }\end{array}$ \\
\hline & $\begin{array}{l}\text { from different } \\
\text { voltameter. }\end{array}$ & 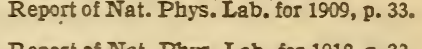 \\
\hline $\begin{array}{l}\text { Do.... } \\
\text { Do.... }\end{array}$ & $\begin{array}{l}\text { Description of new form of roitameter. } \\
\text { On electrostenolysis in the silver } \\
\text { voltameter. }\end{array}$ & $\begin{array}{l}\text { Report of Nat. Phys. Lab. for 1910, p. 32, } \\
\text { Report of Nat. Phys. Lab. for 1911, p. } 33 \text {. }\end{array}$ \\
\hline 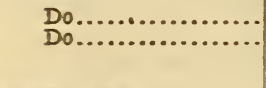 & $\begin{array}{l}\text { Reriew of Bureau of Standards prork.- } \\
\text { Present condition of work on electrical } \\
\text { units at National Physical Labora- } \\
\text { tory. }\end{array}$ & $\begin{array}{l}\text { Rev, Gen. Sci., 24, p. 216; } 1913 . \\
\text { British Assoc. Repori for 1907, p. } 75 .\end{array}$ \\
\hline Smith, editor...... & $\begin{array}{l}\text { British Association reports on electrical } \\
\text { standards. }\end{array}$ & Cambridge University press, 1913. \\
\hline $\begin{array}{l}\text { Smith, Mather, and } \\
\text { Iowry. }\end{array}$ & The silver voltamete & $\begin{array}{l}\text { Phil. Trans., 207A, p. 545, Col. Re- } \\
\text { searches, Nat. Phrs. Lab. 4, P. 125, } \\
\text { 1908. Report of Nat. Phys. Lab. for } \\
\text { 1907, p. 30. }\end{array}$ \\
\hline & & $\begin{array}{l}\text { J. Phys } \\
\text { Zs. f. I }\end{array}$ \\
\hline & Thes & 1000,19100 \\
\hline Stephas & $\begin{array}{l}\text { Determination of electrochemical } \\
\text { equiralent of metals without weigh- } \\
\text { ing. }\end{array}$ & $\begin{array}{l}\text { Zs. f. Phys. und Chem. Unter., Ber- } \\
\text { lin, 23, pp. } 150 \text { and 288; } 1910 .\end{array}$ \\
\hline turgeon. & Criticist & $\begin{array}{l}\text { Sturgeon's Ann. of Elec., 1, p. 369; } \\
\text { 1836. }\end{array}$ \\
\hline ule.. & Silver perozynitrate .............. & Zs. E. Anorg. Chem., 24, p. 305; 1900. \\
\hline $\begin{array}{l}\text { Tanatar........... } \\
\text { Thompsom, S.P... }\end{array}$ & $\begin{array}{l}\text { So-called silver perosynitrate........... } \\
\text { Remariss on electrical standards and } \\
\text { the work of the inter. technical com- } \\
\text { mittee. }\end{array}$ & $\begin{array}{l}\text { Zs. f. Anorg. Chem., 28, p. 331; } 1901 . \\
\text { J. Inst. Elec. Eng., 50, p. 310; } 1912 .\end{array}$ \\
\hline $\begin{array}{l}\text { Thöldte ................ } \\
\text { Tommassi.......... }\end{array}$ & Galvas & $\begin{array}{l}\text { Ann. d. Phys., 18, } \\
\text { Electrochimie, 8, p. }\end{array}$ \\
\hline an Dilk... & Electrochemical equivalent of silver... & \\
\hline Do...... & $\begin{array}{l}\text { Influence of heating the silver voltame- } \\
\text { ter to redness on the electrochemical } \\
\text { equivalent. }\end{array}$ & Arch. Neer. Sci., 10, p. 277; 1905. \\
\hline & The silver voltameter............. & Gebroeders Hoitsema, Groningen; \\
\hline & $\begin{array}{l}\text { The electrochemical equivalest of } \\
\text { silver. }\end{array}$ & $\begin{array}{l}\text { Ann. d. Phys., 19, p. } 249 \text { and 21, p. 845; } \\
\text { 1906. }\end{array}$ \\
\hline Van Dijk and Kunst. & $\begin{array}{l}\text { A determination of the electrochemical } \\
\text { equivalent of silver. }\end{array}$ & $\begin{array}{l}\text { Kon. Alzad. Weten, Amsterdam, 6, p. } \\
\text { 441, 1903; Versl. Wis. Nat. K. K. } \\
\text { Akad. Wet., 12, p. 637, 1903; Ann. d. } \\
\text { Phys., 14, p. 569, 1904. }\end{array}$ \\
\hline Vanai. & $\begin{array}{l}\text { On the apparent variations in the } \\
\text { electrochemical equivalent of copper. }\end{array}$ & $\begin{array}{l}\text { Wied. Ann., 44, p. 214, 1891; Lum. } \\
\text { Electr., 42, p. 192, 1891; Electro, 28, } \\
\text { p. 12, 1891. }\end{array}$ \\
\hline Vlual....... & $\begin{array}{l}\text { Esperiments with different types of } \\
\text { roltameters. }\end{array}$ & Sci., 34, p. 31; 1911. \\
\hline Vinal and Bates & $\begin{array}{l}\text { son of the siver and iodine } \\
\text { eters and the value of the } \\
\text { ay. }\end{array}$ & $\begin{array}{l}\text { Bull. Bur. of Stds., 10, p. 425; J. Wash. } \\
\text { Acad. Sci., 4, p. 69, } 1914 \text {. }\end{array}$ \\
\hline & $\begin{array}{l}\text { Inclusions in the silver voltameter } \\
\text { deposits. }\end{array}$ & $\begin{array}{l}\text { Bull. Bur. of Stds., 13, p. 147; J. Am. } \\
\text { Chem. Soc., 38, p. 496, 1916. }\end{array}$ \\
\hline Vogel. & $\begin{array}{l}\text { On the state in } \\
\text { down by reduc }\end{array}$ & Pogg. Ann., 193, p. 316; 1862. \\
\hline Wasbbum and Bate & $\begin{array}{l}\text { The iodine coulometer and the value } \\
\text { of the Faraday. }\end{array}$ & $\begin{array}{l}\text { J. Am. Chem. Soc., 34, pp. } 1341 \text { and 1515; } \\
1912 \text {. }\end{array}$ \\
\hline Watso & $\begin{array}{l}\text { Value of the earth's field in interna- } \\
\text { tional units. }\end{array}$ & Phil. Trans., 198A, p. 431; 1902. \\
\hline $\begin{array}{r}\text { Do } \\
\text { Weber }\end{array}$ & $\begin{array}{l}\text { Silver diozide and pero } \\
\text { Determination of the e } \\
\text { equivalent of silver. }\end{array}$ & $\begin{array}{l}\text { J. Chem. Soc., } 89 \text {, p. } 578 ; 1906 . \\
\text { Unknown, see Lumiere Electr., 22, } \\
\text { p. } 51 ; 1886 .\end{array}$ \\
\hline & $\begin{array}{l}\text { Remarks on organic matter and silver } \\
\text { oxide in the voltameter. }\end{array}$ & Trans. A. I. E. E., 6, p. 330; 1839. \\
\hline Whitne & y of Faraday's law at low tem- & $\begin{array}{l}\text { Zs. E. Elektrochem., 12, p. 713; } 1906 . \\
\text { J. Phys. Chem., 13, D. 384; } 1909 .\end{array}$ \\
\hline $\begin{array}{l}\text { Wohwil } \\
\text { Wolf.. }\end{array}$ & $\begin{array}{l}\text { Crumbling of the anode.......... } \\
\text { The so-called international unit }\end{array}$ & $\begin{array}{l}\text { Zs. f. Elektrochem., 9, p. 311; } 1903 . \\
\text { Bull. Bur. of Stds., 1, p. } 39,1904 \text {; Trans. } \\
\text { Int. El. Cong., St. Louis, 1, p. 148, } \\
1904 . \text {. } \\
\text { Bull. Bur. of Stds., 5, p. } 243 ; 1908 .\end{array}$ \\
\hline
\end{tabular}




\section{Appendix B.--ERRATA TO OUR PRECEDING PAPERS}

Some few errors in our previous papers have come to our attention. None of these are serious so far as the reading of the papers is concerned except the two errors in designating the curves in Figs. I and 3 of the paper entitled "Studies on the silver voltameter" as published in the Journal of Physical Chemistry. In these two cases the manuscript as it left the authors' hands was correct. The changes that caused these errors were made without the knowledge of the authors.

Except for these corrections and a few mistakes in the footnotes it would be unnecessary to publish these errata so far as the other corrections are concerned.

Errata.

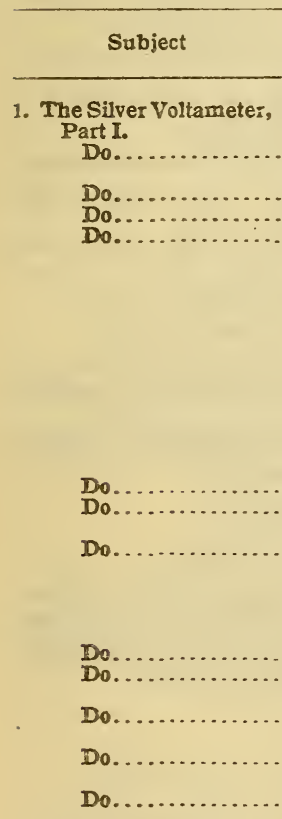

2. The Silver Voltameter, Part II.

Do...

Do.

Do...................

3. The Silver Voltameter, Part III.

Do................

Do ..............

4. The Silver Voltameter, Part IV.

Do................

Do

Do..................
Publication

This Bulletin, 9, p. 153 .. This Bulletin, 9, pp. 154155.

This Bulletin, 9, p. 156.. This Bulletin, 9, p. 157. This Bulletio, 9, D. 158 .

This Bulletin, 9, p. 160.. This Bulletin, 9, p. 161. This Bulletin, 9, p. 173 .

This Bulletin, 9, p. 202.. This Bulletin, 9, p. 204 .

J. Wash. Acad. Sci., 2,

J. Wash. Acad. Sci., 2, p. 455.

J. Wash. Acad. Sci., 2, p. 456 .

This Bulletin, 9, p. 223.:

J. Wash. Acad. Sci., 2, p. 511.

Elect. World, 60, p. 1262 Electrotech., Zs., 34, p. 233.

This Bulletin, 9, p. 498.

This Bulletin, 9, p. 502 This Bulletin, 9, p. 515 . This Bulletin, 9, p. 523

This Bulletin, 10, p. 488 . This Bulletin, 10, p. 489 .

This Bulletin, 10, p. 490 . This Bulletin, 10, p. 510 . .
Footnote 6, instead of volume " 140 " read "149."

Footnotes 13, 14, 15, instead of "Ann. d. Phys." rea "Wied. Ann."

Footnote 22, instead of page "631" read " 630 ."

Footnote 29, instead of volume " 8 " read " $7,0.257$. "

Line 19, the data for this experiment were accident. aliy omitted from the second paper. It is as follows: Feb. 12, 1910. Two cups containing silver deposits were filled with electrolyte and allowed to stand two bours, when they were washed and dried as usual. Newly prepared electrolyte which had been contaminated with filter paper was put in cup No. 125 and the deposit in this cup appeared to gain 0.09 mg. The electrolyte put in cup No. 126 was clear anode liquid taken from inside of several porous cups after an ordinary experiment. The deposit in this cup appeared to lose $0.03 \mathrm{mg}$.

Line 27 , instead of "Snowden" read "Snowdon."

Footnotes 45 and 46 , instead of "El. ch." read "Electrochem."

Middle of the page, instead of "Poggendorff" read "Kohlrausch." For the explanation of this change, see page 484 of this paper. We shall not attempt to inclicate in this errata the many places which this change involves.

Footnote 68, after "Phil. Trans. A186" insert "p. 630." Footnote 70, instead of "second paper" read "third paper, page 512 ."

Line 26, instead of "former" read "latter."

Line 10, instead of "they" read "the cathodes."

Line 3 from end, instead of " 1.018287 " read " 1.01828 ;."

Footnote 9, instead of "Elec. ch." read "Electrochem."

Line 11, instead of " 1000 " read " 300. ."

Line 3 from end of page, instead of " 1000 " read " 300 ", Middle of last column, instead of " 1000 " read " 300 ."

Iine 3 from bottom, instead of "Frankfort" read "Frankfurt."

Sirth column of table, take out "second half."

Footnote 6, insert " 10, p. 157. "

Footrote 7, instead of "Elec. chem" read "Electrochem."

Footnote 13 applies to the first line of Nov. 15 and not to Nov. 5.

Second observation of Feb. 20, "large size" ought to be in "medium size."

Footnote 15 applies also to the observations of Mar. 12. Line 14 of text, add the following: "Dr.von Steinwehr has explained to us since this was written that he does not consider this form of voltameter with sill as a Kohirausch voltameter." 


\section{Errata-Continued}

\begin{tabular}{|c|c|c|}
\hline Subject & Publication & Change \\
\hline 4. The Silver Voltameter, & This Bulletin, 10, p. 518 .. & Footnote 34, instead of page " 246 " read " 252. ." \\
\hline Do............................. & $\begin{array}{l}\text { This Bulletin, 10, p. } 524 . . \\
\text { This Bulletin, 10, p. } 536 . .\end{array}$ & $\begin{array}{l}\text { Footnote 41, instead of page "64" read " } 1364 . " \\
\text { Conclusion } 4 \text { has led to misunderstanding on the } \\
\text { part of those who have apparently not read the more } \\
\text { detailed discussions which precede it. It should be } \\
\text { expanded to read as follows: "We have made some } \\
\text { experiments on the inclusions of the deposited } \\
\text { silver and conclude that when pure electrolyte is } \\
\text { used the inclusions are very small or rery constant } \\
\text { in amount, so that the roltameter as a standard } \\
\text { instrument for the measurement of electric current } \\
\text { is satisfactory, when used according to proper } \\
\text { specifications." }\end{array}$ \\
\hline Do.. & J. Wasi. Acad. Sci., 4, & Line 29 , instead of "0.053 mg" read "0.53 mg." \\
\hline 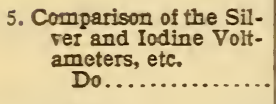 & This Bulletin, 10, p. 437 . & $\begin{array}{l}\text { Footnote 7, add "and p. 494, repriat No. 201." } \\
\text { Line } 3 \text { from bottom, omit one of the three l's in "espe. }\end{array}$ \\
\hline $\begin{array}{l}\text { Do. } \\
\text { Do. }\end{array}$ & $\begin{array}{l}\text { This Bulletin, 10, p. } 443 . \\
\ldots \ldots \text { do.......................... }\end{array}$ & $\begin{array}{l}\text { Line 23, instead of "Amer" re } \\
\text { Footnote 15, instead of "Ann. }\end{array}$ \\
\hline 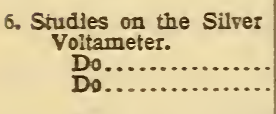 & $\begin{array}{l}\text { This Bulletin, 11, p. } 557 . . \\
\text { This Bulletio, 11, p. } 558 \text {.. } \\
\text { This Bulletin, 11, p. } 566 . .\end{array}$ & $\begin{array}{l}\text { Line 15, instead of "Table 10" read "Table } 11 " \\
\text { (this error in first printing only). } \\
\text { Line } 7 \text {, instead of "was" read "were." } \\
\text { Table } 9 \text { should be Table } 10 \text { (this error in first printing } \\
\text { only). }\end{array}$ \\
\hline Do. & This Bulletiv, 11, p. 568 .. & $\begin{array}{l}\text { Table } 10 \text { should be Table } 11 \text { (this error in ferst } \\
\text { printing only). }\end{array}$ \\
\hline Do. & This Bulletin, 11, p. $569 .$. & Table 11 should be Table 12 (this error in first \\
\hline Do. & J. Wash. Acad. Sci., 4, & Line 14, instead of "to it stand" read "it to stand." \\
\hline & J. Phys. Chem., 19, p. & Lice 7, instead of "Table X" read "Table XI." \\
\hline Do. & $\begin{array}{l}\text { J. Phiss. Chem., 19, p. } \\
183 .\end{array}$ & $\begin{array}{l}\text { Fig. 1, the curve marked " } T \text { " should be "II", and } \\
\text { vice versa to correspond with the tert on pages } 182 \\
\text { and } 186 .\end{array}$ \\
\hline Do. & $\begin{array}{l}\text { J. Phys. Chem., 19, p. } \\
\text { 187. }\end{array}$ & $\begin{array}{l}\text { Fig. 3, the curve marked "I" should be "II" and } \\
\text { Fice versa to correspond with the tert on page } 187 \text {. }\end{array}$ \\
\hline Do. & J. Phys. Chem., 19, p. & "Table IX" should be "Table X." \\
\hline & J. Phys. Chem., 19, p. & "Table X" should be "Table XI." \\
\hline Do. & J. Phys. Chem., 19, p. & "Table XI" should be "Table XII." \\
\hline $\begin{array}{l}\text { 7. Irelusions in the Volt- } \\
\text { ameter Deposits. }\end{array}$ & J. Am. Chem. Soc., 38 & $\begin{array}{l}\text { Table I, in compiling this table one observation was } \\
\text { orerlooked, but this omission has no significant } \\
\text { effect on the mean result or the conclusions drawn } \\
\text { trom it. This table as published in the Bulletin } \\
\text { of the Bureau of Standards is complete. }\end{array}$ \\
\hline
\end{tabular}

